\title{
0 caos organizado de Egberto Gismonti em Frevo: improvisação e desenvolvimento temático
}

\author{
Marcelo G. M. Magalhães Pinto (UFMG, BH, MG; Eastman School of Music, Rochester, EUA) \\ mmagalhaespinto@gmail.com
}

Fausto Borém (UFMG, Belo Horizonte, MG)

fborem@ufmg.br

Resumo: Estudo analítico sobre as práticas composicionais e improvisatórias de Egberto Gismonti na sua música Frevo para piano, especialmente na interseção entre os procedimentos de desenvolvimento temático e improvisação. A partir da versão gravada no disco Alma (GISMONTI,1987a), cuja transcrição foi realizada pelos autores do presente artigo e publicada no presente volume de Per Musi (GISMONTI, 2013, p.125-144), observa-se como Gismonti obtém grande unidade na realização de Frevo a partir da recorrência e diversas transformações de apenas cinco motivos ao longo da obra. A análise também revela uma hibridação de elementos da música popular (frevo, jazz, improvisação) e erudita (com reflexos de métodos da técnica para piano, J. S. Bach, F. Chopin, H. Villa-Lobos, da Primeira e Segunda Escolas de Viena e do período pós-1950).

Palavras-chave: música para piano de Egberto Gismonti; práticas composicionais e improvisatórias; hibridismo entre música popular em música erudita; frevo na música brasileira.

\section{The organized chaos of Egberto Gismonti in Frevo: improvisation and thematic development}

\begin{abstract}
Analytical study about the compositional and improvisational practices of Egberto Gismonti in his music Frevo for piano, especially in the intersection between the procedures of thematic development and improvisation. Departing from the audio track included in the Alma album (GISMONTI, 1987a), which transcription was realized by the authors of the present article and published in the present volume of Per Musi (GISMONTI, 2013, pp.125-144), it reveals how Gismonti achieves great coherence in the realization of Frevo by resorting to the recurrence and varied transformation of only five motives throughout the work. The analysis also reveals a hybridization of elements from popular music (the Brazilian frevo, jazz, improvisation) and classical music (reflecting piano technique methods, J. S. Bach, F. Chopin, H. Villa-Lobos, the First and Second Vienna Schools and the post-1950 period).
\end{abstract}

Keywords: piano music by Egberto Gismonti; compositional and improvisational practices; hybridism between popular and classical music; frevo in Brazilian music. 


\begin{abstract}
"...se o samba diverte, o frevo fere; e isto está expresso nos símbolos, na expressão visual, na música e na dança do frevo." (Depoimento de Paula Valadares a MÜLLER, 2006)

"...surgiu das camadas menos favorecidas, que 'resistiam' ao poder das elites, e que hoje resiste aos poderes do mercado, que não o privilegiam..." (MÜLLER, 2006)
\end{abstract}

\section{1 - 0 gênero frevo e a canção instrumental Frevo}

Do ponto de vista etimológico, o frevo tem origem no verbo ferver, que era pronunciado erroneamente "frever" pelas camadas sociais com menos instrução escolar (LIMA, 2005). Do ponto de vista musical, a origem da palavra sugere a agitação, efervescência e euforia características da dança frevo, remetendo, nas palavras de SALDANHA $(2008$, p.2) a "um êxtase do movimento corpóreo em coreografia que leva à insanidade ou delírio de animação". Do ponto de vista social, o frevo reflete os polos opostos e ainda conflitantes da colonização escravagista do nordeste brasileiro no final do século XIX. De um lado, o frenesi dos passos acelerados (os tradicionais "chutando de frente", "pernada", "abre-alas", "rojão" e "tramela", ou os mais modernos, como "malandro", "martelo rodado" e "meia-lua"), derivados da capoeira, ainda hoje sugerem a atmosfera de agressividade e defesa dos negros libertos no ambiente de agitação em que se encontrava o Recife do início do século XX (LÉLIS, 2007, p.27, 76). Do outro, a repressão militar, que se reflete como influência direta do dobrado das bandas militares no seu estilo e instrumentação. 0 próprio GISMONTI (2009) admite que o seu Frevo é muito próximo do gênero dobrado. No programa Ensaio da TV cultura, em 1992, ele narra:

[01:01] Ah...essa história de frevo... aliás, o pessoal de Olinda e Recife que me perdoe... eu acabei fazendo um frevo porque eu ouvi muito dobrado... [01:16] Tio Edgar tocava o dobrado dele [cantando uma linha do baixo, imitando um bombardino... 'pó, pó, pó, pó-róró-pó-pó"]... [01:26] e eu vim pensando nisso e fiz um dobrado que se chama Frevo [começa a tocar Frevo, cantarolado junto]... que parece que não é dobrado mas é [enquanto fala, toca acelerando o andamento]... é um frevo mas é dobrado... [05:20, após terminar de tocar] É um frevo, mas é um dobrado...aliás o [percussionista] Naná [Vasconcelos], sempre me dizia... esse teu Frevo mais parece um dobrado... mas que é um frevo! ... Naná de Olinda!...

Um grande impulso foi dado ao gênero com a criação da Fábrica de Discos Rozenblit no Recife em 1954, que dava preferência aos ritmos regionais e que, na década de 1960 , respondeu por $22 \%$ da produção de discos no Brasil (VALADARES 2007, p.85-86). Embora as primeiras referências ao gênero estejam se encontrem em letras de canções (como em Sá Zeferina tá de vorta, de 1930, de Valdemar de Oliveira, na voz de Mário Pessoa) ou em títulos de canções (como Frevo Pernambucano, de Luperce Miranda e Oswaldo Santiago, de 1930, na voz Francisco Alves) (VILA NOVA, 2012, p.99-100), há uma gravação de 1905 do frevo instrumental A Província, de Juvenal Brasil (SALDANHA, 2008, p.89). Isto reforça a ideia do frevo instrumental ter surgido antes do frevo cantado. 0 frevo, cujo apogeu como música radiofônica se deu entre a segunda metade da década de 1950 e o final da década de 1960, está indelevelmente associado à cultura musical de Pernambuco e foi reconhecido como Patrimônio Imaterial Nacional pelo IPHAN (Patrimônio Histórico e Artístico Nacional) em 28 de fevereiro de 2007 (SANT'ANNA, 2007).

Diversos autores (VILA NOVA, 2012, p.36; LIMA, 2005; SALDANHA, 2008; RIBEIRO, 2008) identificam, já na década de 1930 e a partir do registro em discos e partituras, uma tipologia tripartite do gênero: (1) o frevode-rua, tocando ao ar livre com grupos instrumentais, especialmente com sopros e percussão em andamento rápido; (2) o frevo-de-bloco (ou marcha-de-bloco) baseado nos grupos tradicionais com instrumentos de corda das antigas marchas carnavalescas; e (3) o frevo-canção que surgiu inicialmente com a aposição de letra ao frevo-de-rua, rápido e acompanhado por instrumentos de sopro e que foi objeto de polêmica sobre sua legitimidade dentro do gênero.1 A partir de 1980, o frevo-de-rua e o frevo-canção passaram a contar com as freviocas, carros ambulantes que permitem seu acompanhamento pelas multidões nas ruas. 20 frevode-rua apresenta pelo menos três variações: (a) o frevodo-abafo (ou frevo-do-encontro, como Fogão de Alfredo Lisboa), no qual fanfarras rivais tentam abafar o som uma das outra por meio de melodias com notas agudas e de longa duração em fortissimo; (b) o frevo coqueiro (como Duda no frevo de Senival "Senô" Bezerra do Nascimento), no qual predominam trechos virtuosísticos agudos e contraponto, e, alusão ao nome, com muitas semicolcheias escritas acima do pentagrama; (c) o frevo ventania (como Tempestade de Joaquim Wanderley), no qual também predomina o virtuosismo, especialmente nos instrumentos de palheta, com predomínio da melodia acompanhada no registro médio e menos contraponto, tipicamente o saxofone com linhas "em ventania", (LIMA, 2005; SALDANHA, 2008; RIBEIRO, 2008; C. S. ANDRADE, 2008; LÉLIS, 2007, p.69). Edson Rodrigues, citado por SILVA e SOUTO MAIOR (1991, p.66), ainda menciona, entre os novos compositores de frevo, o frevo-de-salõo, que apresenta influências do jazz na harmonia e melodia. Em um relato da década de 1920, outra alusão ao jazz é 
feita em relação à sensação de "caos" contrapontístico que pode causar no ouvinte:

\begin{abstract}
"O ensaio geral do Clube Vassourinhas veio varrer os últimos resquícios de tristeza da alma romântica da cidade... Ontem, quem esteve na Rua Nova, na Praça da Independência e na Rua Imperador, ali por volta das 24 horas, viu claramente o que quer dizer: frevo pernambucano...Um delírio, um frenesi, um arranca rabo de todos os diabos... A música, numa apoteose jazz bandesca, desequilibrando todas as acústicas num verdadeiro pandemônio de tons". (trecho do Diário de Pernambuco de 29 de fevereiro de 1924, citado por RABELLO, 2004, p.127).
\end{abstract}

Outras características estilísticas importantes do frevo são: predomínio da forma canção

$[A:\|B:\| A]$ (muitas vezes com pontes ligando as Seções $A$ e B), andamentos rápidos, com pulsação binária em $2 / 4$ (às vezes escrita em $4 / 4$ ), introdução melódica com anacruse, longos fraseados em movimento ascendente ou descendente, trechos em cromatismo, escrita virtuosística e finais apoteóticos (SALDANHA, 2008; RIBEIRO, 2008). Já em relação ao andamento, o dossiê do frevo no IPHAN (LÉLIS, 2007, p.66) faz referências aos andamentos típicos de frevo: seminima entre 100-120 para o frevo-de-bloco; 130-150 para o frevo-de-rua, e até $140-160$ para o frevo-canção.

Estilisticamente, Frevo de Egberto Gismonti faz alusão ao frevo coqueiro, com suas passagens no registro agudo, virtuosismo e instrumentação contrapontística. Já sua utilização de harmonia modal, acordes alterados e improvisação na forma remete ao frevo de salão. $\mathrm{Na}$ performance de Frevo no disco Alma, Egberto Gismonti, refletindo sua formação erudita no piano, utiliza um andamento ainda mais virtuosistico, com semínima variando entre 224 e 232, o que torna esta versão, com toda a complexidade de suas polirritmias, difícil mesmo para pianistas experientes.

Como muitas outras expressões musicais populares, o frevo foi se adaptando ao longo de sua história a demandas como inclusão de letras, forma de apresentação, participação do público e acústica dos ambientes, o que gerou mudanças e variações na instrumentação de suas bandas:

\footnotetext{
"A instrumentação do frevo-de-rua é, pois, a instrumentação emblemática do gênero. É a orquestra de instrumentos de sopro e percussão, com predomínio de instrumentos de bocal (trompetes, trombones, tuba) e participação de instrumentos do naipe dito "das madeiras" (embora alguns destes instrumentos sejam hoje feitos de metal): saxofones, clarinetes, requinta, flauta e flautim; a percussão composta de surdo, caixa e pandeiro. Esta seria a formação mais clássica, diretamente inspirada das bandas marciais. Na prática mais recente, porém, os instrumentos de sopro têm-se resumido a saxofones, trompetes e trombones, e se têm adicionado alguns instrumentos eletrônicos, como teclados, guitarra e baixo elétrico (este último bastante comum como substituto da tuba)". (LÉLIS, Org., 2007, p.63).
}

Na sua visão do frevo, Egberto Gismonti buscou refletir a instrumentação típica do gênero, explorando registros e timbres no piano, de modo a sugerir a interferência marcante dos metais, as linhas melódicas rápidas e sincopadas das madeiras, a articulação explosiva da percussão, combinadas em complexas polirritmias resultantes dessa interação.

Embora existam duas partituras do Frevo publicadas pelo próprio Egberto Gismonti - uma incluida no encarte do disco Alma (GISMONTI, 1987b) e outra publicada pela Éditions Gismonti Suisse (GISMONTI, s.d.) -, preferimos outra fonte primária para esse trabalho: a gravação em áudio incluida no disco Alma (GISMONTI, 1987a), que, além das seções da forma canção $A A B A$, contem ainda uma Ponte, uma Coda e uma importante seção de improvisação com seis choruses de recapitulação da Seção A. Nessa gravação, Gismonti também inclui discretas intervenções dele e de Nando Carneiro no teclado eletrônico como ambiências e reforço tímbricoharmônico em [01:10 da gravação] (ou c.73 da partitura transcrita), [01:32] (ou c.94), [01:59] (ou c.122), [03:40] (ou c.226), [03:54] (ou c.242) e [05:53] (ou c.347) . A partir dessa gravação, os autores do presente artigo realizaram a transcrição da partitura de Frevo (processo no qual foram utilizados os softwares Finale e Amazing Slow Downer), sem a parte de teclado eletrônico da gravação. Em relação às dinâmicas nessa transcrição foram anotadas apenas algumas sugestões a partir da gravação, mesmo porque o próprio Gismonti questiona a colocação desses sinais nas partituras de suas músicas:

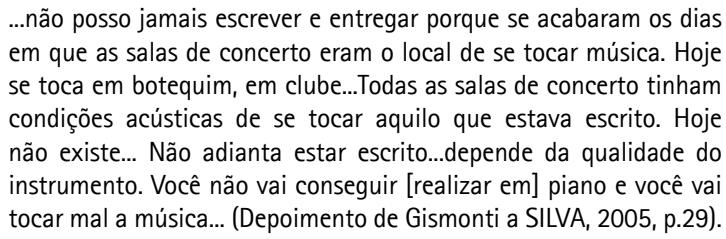

...não posso jamais escrever e entregar porque se acabaram os dias em que as salas de concerto eram o local de se tocar música. Hoje se toca em botequim, em clube...Todas as salas de concerto tinham condições acústicas de se tocar aquilo que estava escrito. Hoje não existe... Não adianta estar escrito...depende da qualidade do instrumento. Você não vai conseguir [realizar em] piano e você vai tocar mal a música... (Depoimento de Gismonti a SILVA, 2005, p.29).

A partitura da transcrição de Frevo utilizada na análise está publicada integralmente no presente volume de Per Musi (GISMONTI, 2013, p.125-144).

\section{2 - Egberto Gismonti no Frevo: compositor- instrumentista, erudito-popular}

Egberto Gismonti nasceu em uma família musical na cidade do Carmo, Rio de Janeiro, em 1947. Começou a estudar o piano erudito por influência do pai libanês e o violão popular por influência da mãe italiana. Com naturalidade, aplicava a técnica de instrumento erudito ao popular. Sua formação erudita ao piano o inspirou a transcrever trechos do Cravo bem temperado de J. S. Bach para o violão (BERNOTAS, 2008). Egberto comenta sobre sua naturalidade nesse trânsito na linguagem dos dois instrumentos:

\footnotetext{
... se você pega uma criança de 6,7 anos de idade e começa a falar 3 linguas como ela, quando tiver 10, fala as 3 linguas e não sabe que tem diferença de uma para a outra. Música para mim foi assim. Comecei a estudar e a tocar dois instrumentos ao mesmo tempo. [Somente] Hoje em dia eu tenho consciência de que violão não tem nada a ver com piano e vice-versa (Depoimento de Gismonti a WANDER, 2007).
}

De fato, a grande extensão do piano acabou levando Egberto a encomendar violões personalizados com 8, 10,12 e 14 cordas, os quais ele utiliza com diversos 

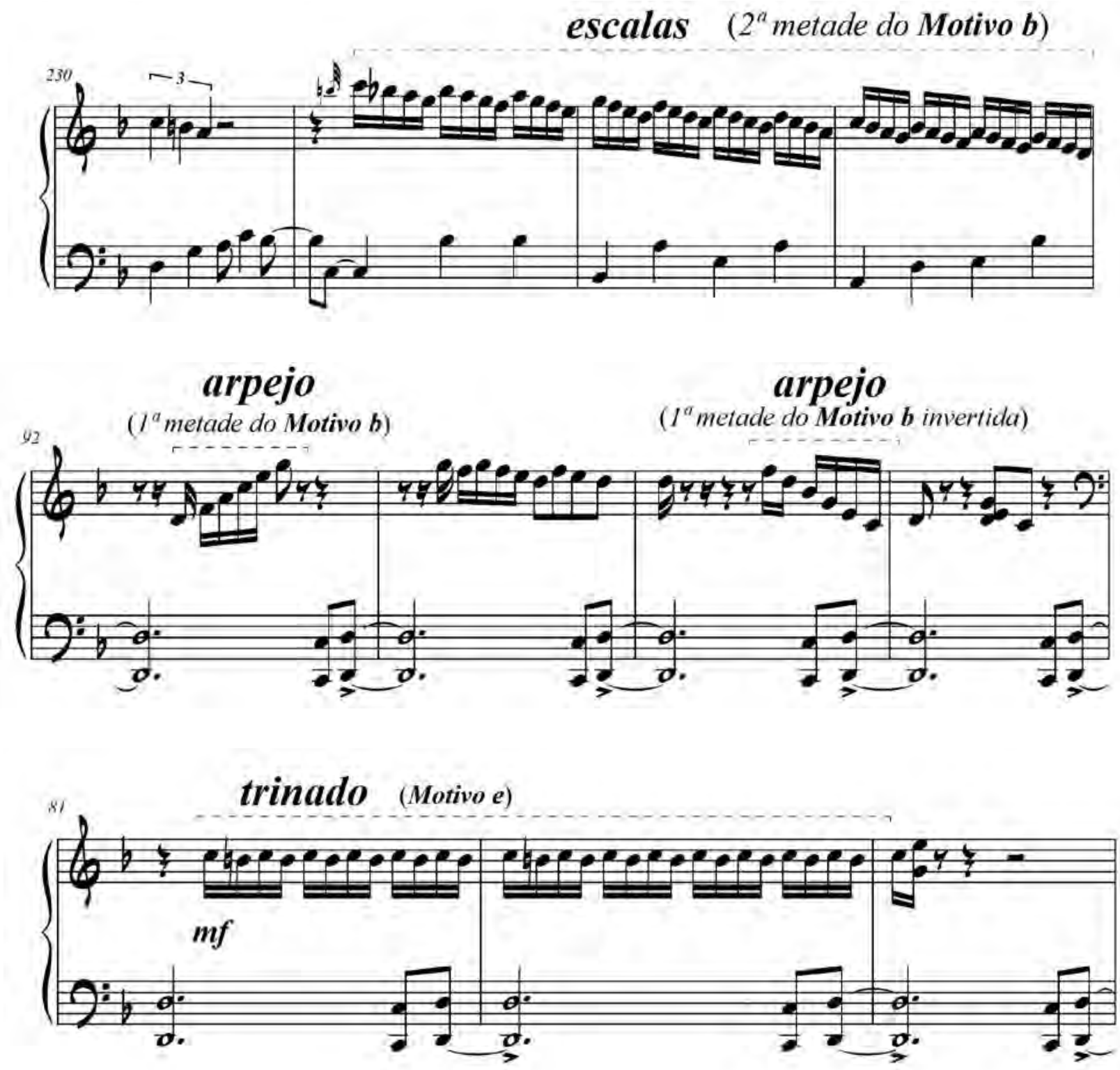

Ex.1a,b, c - Trechos virtuosísticos com escalas (2a), arpejos (2b) e trinados (2c) em transformações do Motivo $b$ e Motivo e de Frevo (para lista e descrição dos motivos, veja Exs. 7 e 8, à frente): herança dos estudos de técnica pianística de Gismonti em conservatório.

tipos de afinação, reforçando a ideia de ampliação da escrita idiomática e das práticas de performance com base no piano:

Basicamente, eu sou um pianista que toca violão. Devido à extensão do piano eu afinei meus ouvidos para intervalos maiores que os intervalos do violão. Esta é a principal razão de usar mais cordas. As afinações são diferentes para cada violão, mas todos eles têm cordas mais altas nas $7^{\mathrm{a}}$ e nas $9^{a}$ (Depoimento de Gismonti a GILMAN, 2009, tradução nossa).

Com relação às influências dos nove anos de estudo em conservatório (SILVA, 2005, p.10), é evidente a herança do repertório tradicional do piano sobre seu estilo crossover. No Frevo, ouvem-se diversos ecos de exercícios de métodos da técnica básica do piano realizados em andamentos rápidos, como trechos de escalas (em que as mudanças de posição com forma de mão direita completa foi utilizada idiomaticamente) iniciados com um ornamento (c.231; Ex.1a), arpejos (c.92, 94; Ex.1b) e trinados (c.81; Ex.1c). Mas não se trata de uma utilização gratuita da técnica, mas de transformações de motivos básicos da peça com o objetivo de desenvolvimento temático (veja lista de motivos básicos no Ex.8 e Ex.9 abaixo).

Podem-se observar também reminiscências de dedilhados próprios do repertório romântico, como a alternância entre 1-4 e 2-5 na mão direita para realizar longas sequências de intervalos de sextas e quintas paralelas. Típicos do pianismo do século XIX, essa técnica aparece, por exemplo, no Étude Op. 25 Nº 8 de Frédéric Chopin (c.1; 
Ex.2a) e recorre em toda a Subseção $D$ (para saber das características de cada subseção, veja Exs.8 e 9, à frente) de Frevo (c.148; Ex.2b), que podemos considerar "a seção romântica" dessa peça.

Reflexos do pensamento contrapontístico e da complexidade rítmica da tradição musical alemã, epitomados nos modelos deixados por J. S. Bach, podem ser ouvidos na música crossover de Gismonti. A condução de vozes no estilo de melodia polifônica (ou falsa polifonia, em que uma voz permanece estática e a outra se move, como ocorre no Prelúdio BWV 848 de BACH (c.2; Ex.3a), pode ser percebida também no trecho do Frevo (c.226; Ex.3b).

A mesma complementaridade entre vozes simultâneas que se observa no Prelúdio BWV 867 do Cravo bem temperado de J. S. Bach (c.13; Ex.4a) é também sugerida por Gismonti no tratamento improvisatório da Subseção $A^{11}$ que leva à Coda do Frevo (c.333; Ex.4b). Essa utilização de uma mão esquerda autônoma dialogando com a mão direita na apresentação de materiais temáticos é incomum no piano popular. Ainda no Ex.4b, o Motivo c é tratado com um pontilhismo espacializado pósweberiano, outra abordagem arrojada entre os pianistas populares, que a encaixariam dentro da linguagem que chamam de outside.
Mas o nível de complexidade rítmica que Gismonti propõe trazer para a seara da música popular instrumental vai além da polifonia de Bach ou o pontilhismo de Webern. Gismonti afirma que Ravel o atraiu por suas orquestrações inovadoras e o contraponto presente nos seus chord voicings (BERNOTAS, 2008). Depois de tocar Frevo no Teatro Colón, em Buenos Aires, no dia 21 de abril de 2003, em um concerto que considera uma de suas performances mais inspiradas e tecnicamente perfeitas (SILVA, 2005, p.17), ele mencionou a complexidade desta obra:

Esse concerto do Colón é um bom parâmetro. Eu não me lembro nesses 30 anos, tocando profissionalmente, de eu ter tocado 90 e tal minutos com uma concentração e uma precisão

muito raras... 0 "Frevo" do Colón é uma das coisas mais complexas que eu já ouvi como resultado do piano que eu toco. É complexo no sentido da polifonia. Quando eu ouço esse troço, eu digo 'mas caçamba, eu nunca tinha tocado esse troço assim!'

De fato, no trecho da Subseção $B$ mostrado no Ex.5, da esperada pulsação binária (ainda que sua escrita original tenha sido em 4/4), ele se lança a uma intrincada polirritmia cuja inspiração lembra a rítmica dos bateristas outside, em que a mão direita faz um desenho ascendente firmemente ancorado na métrica $3 / 8$, enquanto que a mão esquerda, realizando padrões de síncopes inusitadas na métrica 2/4, não fornece um apoio sólido.

\section{F. Chopin - Etude Op.25, N.8}

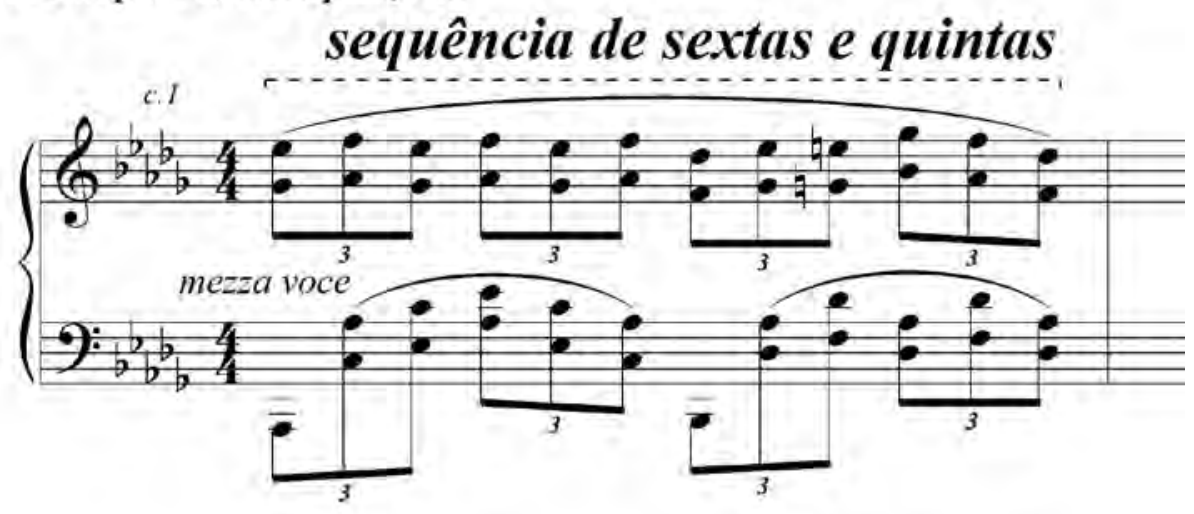

\section{E. Gismonti-Frevo sequência de sextas e quintas $($ Motivo $a+c+f)$}

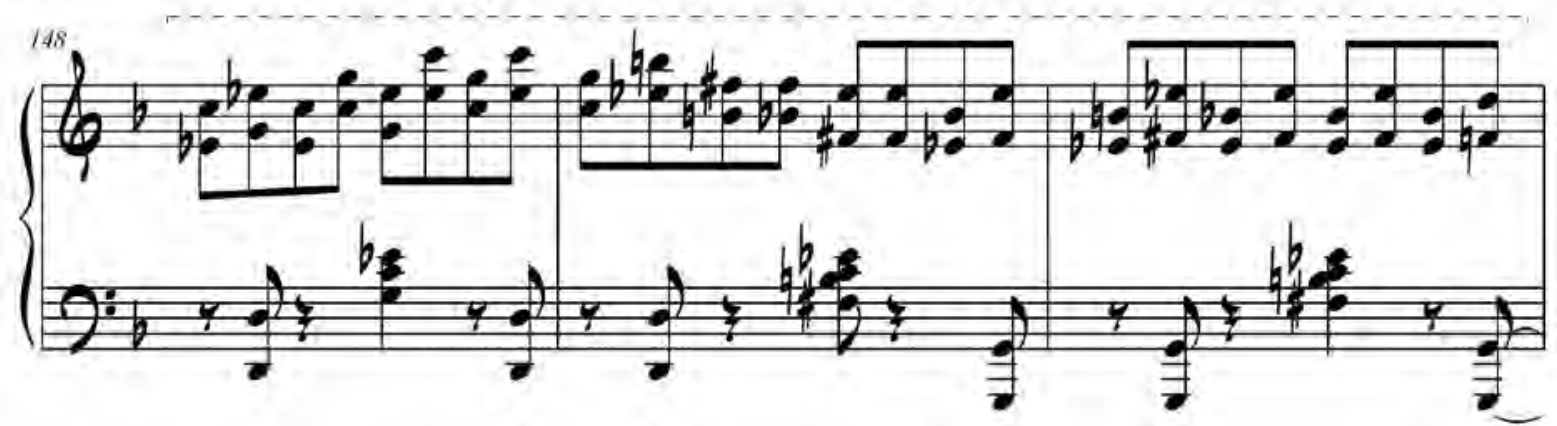

Ex.2a, b - Dedilhado com sequência de sextas e quintas na mão direita do piano: Étude $0 p .25 N^{\circ} 8$ de Frédéric Chopin

(2a) e Subseção D de Frevo de Egberto Gismonti (2b). 

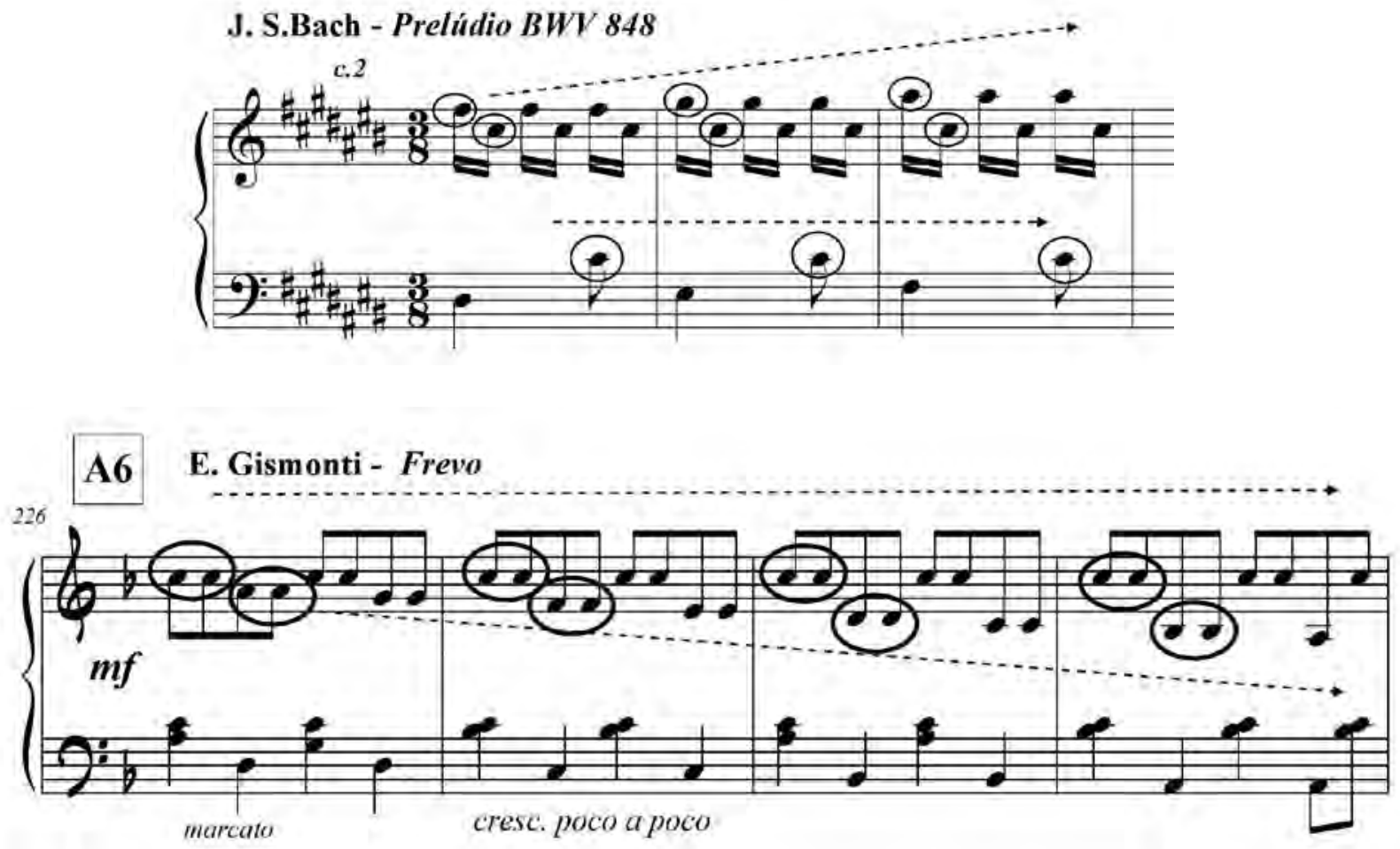

Ex.3a, b - Melodia polifônica no Prelúdio BWV 848 do Cravo bem temperado de J. S. Bach e no Frevo de Egberto Gismonti.

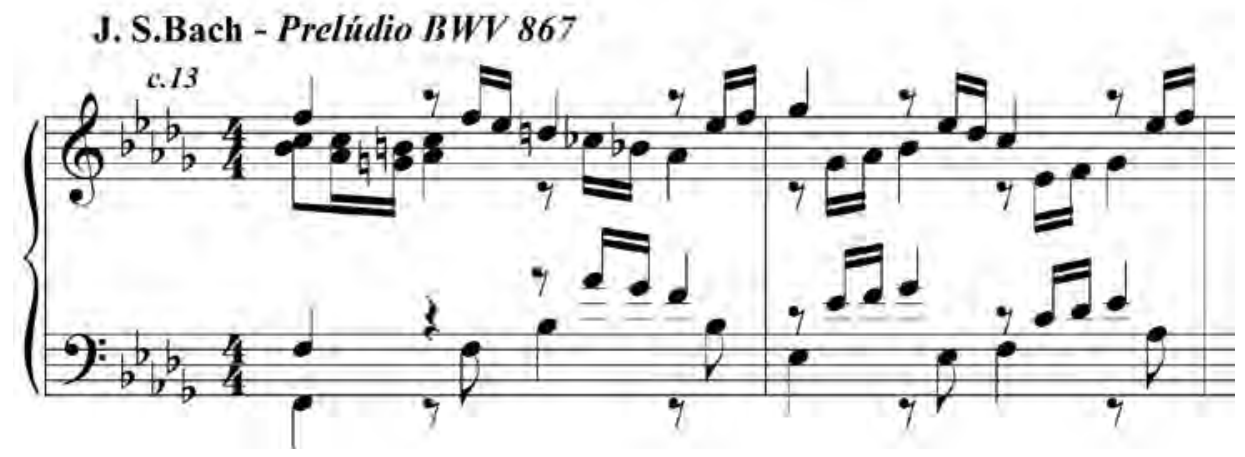

\section{E. Gismonti - Frevo}

\section{Motivo b}

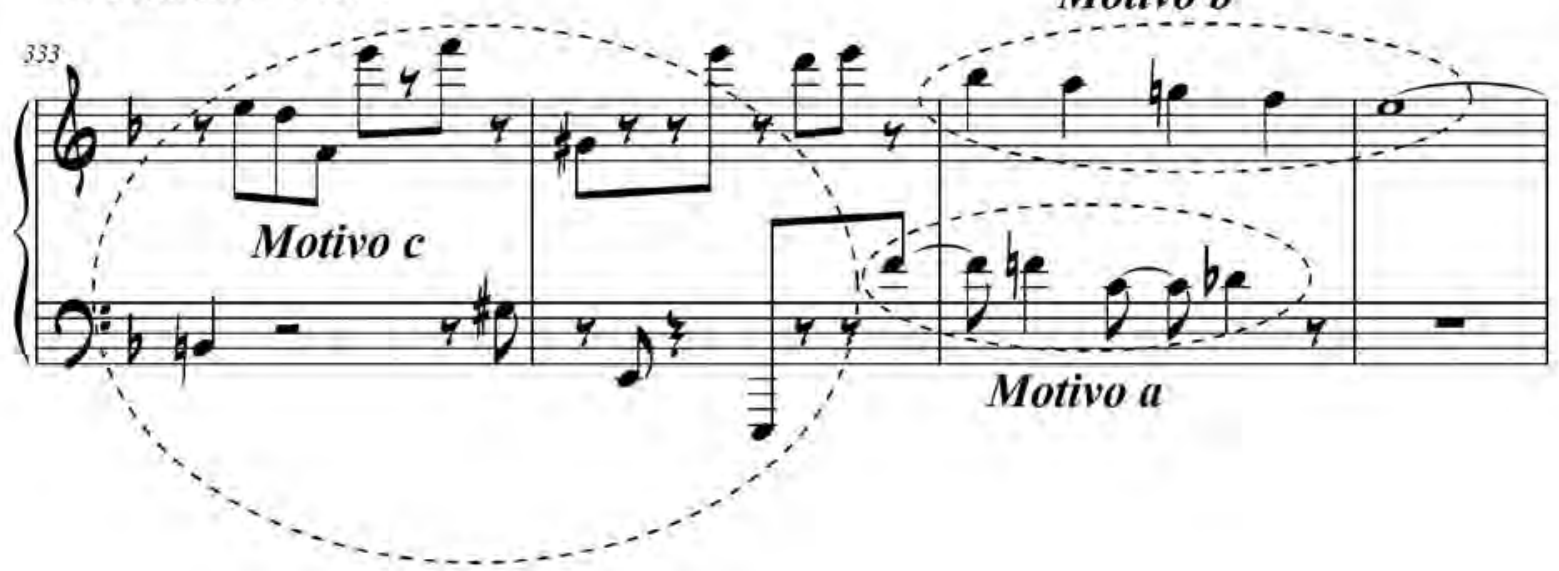

Ex.4a, b - Complementaridade de vozes no Prelúdio BWV 867 do Cravo bem temperado de J. S. Bach e no Frevo de Egberto Gismonti, que também mostra pontilhismo no tratamento do Motivo c. 


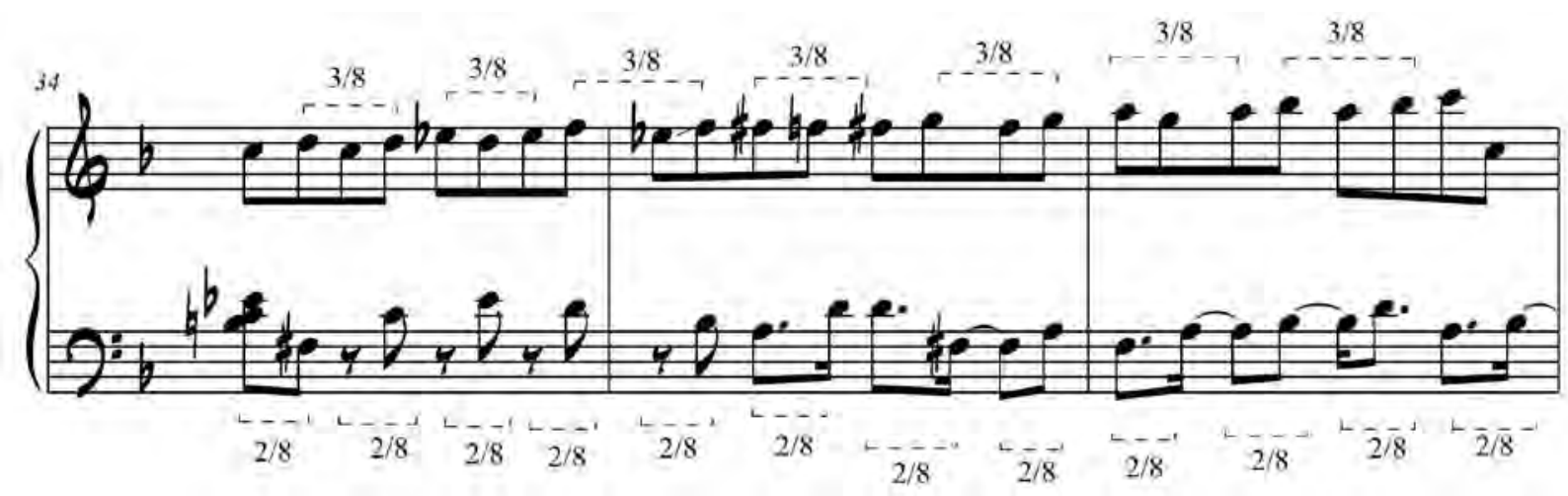

Ex.5 - Complexidade rítmica na Subseção B do Frevo de Egberto Gismonti, comuns em polirritmias jazzísticas.
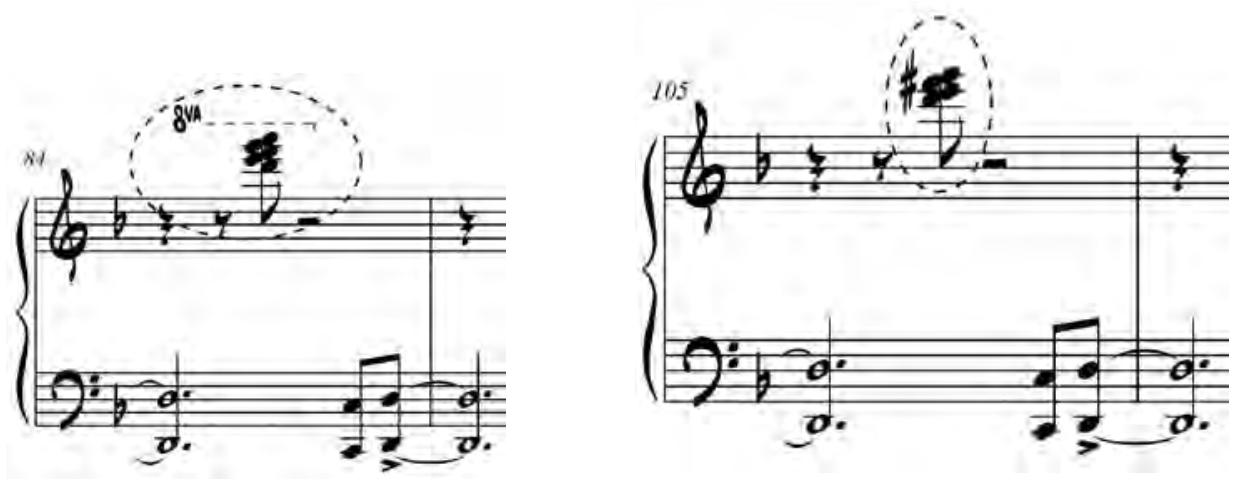

Ex.6a, b - Ocorrência de clusters no Frevo de Egberto Gismonti: traços da música erudita pós-1950.
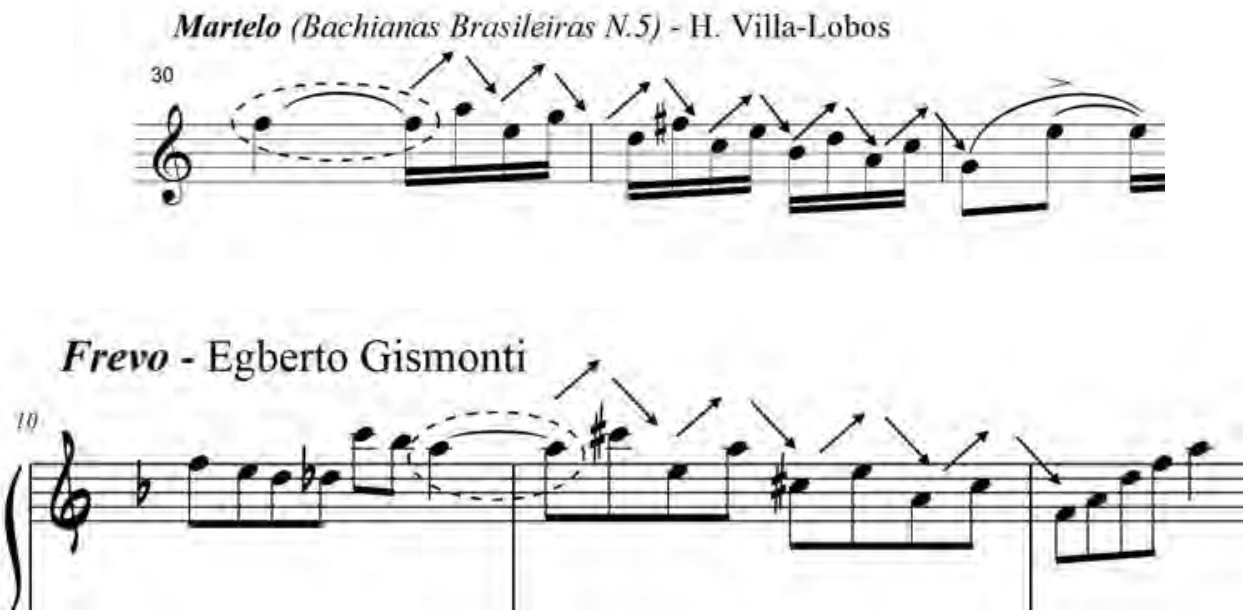

Ex.7a,b - Linha melódica descendente entrecortada após síncope no Martelo das Bachianas Brasilerias N.5 de H. Villa-Lobos e no Motivo c do Frevo de Gismonti.

Além da forte influência da música francesa e da música da $2^{a}$ Escola de Viena, os estudos de Gismonti com Nadia Boulanger e Jean Barraqué em Paris (BERNOTAS, 2008) podem ter colocado Gismonti com elementos típicos da música pós-1950, como a utilização do colorismo nãofuncional dos clusters (c.84, 105; Ex.6a, b),
Mas essa forte influência europeia não impediu que a música de Gismonti soasse irremediavelmente brasileira, com sugere uma comparação de trecho descendente entrecortado após síncope do Frevo (c. 10; Ex.7b) com trecho semelhante do Martelo, que constitui o segundo movimento das Bachianas Brasileiras N.5 de H. Villa-Lobos (c.30; Ex.7a). 
Gismonti fala não só sobre a importância de Villa-Lobos no seu desenvolvimento como músico, mas também de outro ícone do nacionalismo brasileiro:

0 Villa-Lobos foi o sujeito que teve a parabólica mais bem instalada no Brasil. E o mentor da parabólica do Villa-Lobos - parabólica é coisa positiva; quer dizer "antenado" com o Brasil - foi o Mário de Andrade (Depoimento de Gismonti a AMARAL, 2007).

Essa admiração pela cultura brasileira e sua excelência instrumental tanto no piano (de tradição erudita) quanto violão (de tradição popular) reflete bem a sintese que Gismonti sempre buscou e que passou a ser também um modelo para as gerações seguintes. OLIVEIRA (2009, p.17) comenta esta trajetória de Gismonti, na qual foi um dos responsáveis pela inclusão do repertório crossover no meio erudito, facilitando

\begin{abstract}
... a adoção de várias obras que anteriormente eram somente aceitas no ambiente da música popular em recitais de violão erudito. Vários concertistas ativos [como Sérgio Assad] naquele periodo se aventuraram em projetos de gravações e concertos com obras de caráter popular...,
\end{abstract}

e também por influenciar estilisticamente compositores reconhecidos internacionalmente como Sérgio Assad (OLIVEIRA, 2009, p.145-147, 193, 213). MELO (2007) comenta sobre a presença e a transfiguração dos traços folclóricos na obra de Gismonti, o que observaremos na análise de Frevo:

Egberto é um artista brasileiro cujos rótulos dizem muito pouco sobre sua música. É difícil negar seus traços "populares", ainda que bem mais complexos que as manifestações folclóricas ou da música popular de massa que tomou a forma das canções. 0 estatuto do "popular" em sua obra é sempre refletido e mediatizado nos procedimentos composicionais. 0 regional nunca vai sem uma pitada de novidade ou sem um sentimento de traição com o passado e com a herança cultural.

Mas no círculo de músicas que o influencia, Gismonti não excluiu a dita música de massa. Em entrevista publicada no site Clube do Jazz (PIRES, 2004), Gismonti vê com bons olhos a oportunidade de receber influências as mais diversas e, por isso, parece não se impor preconceitos com relação a quaisquer formas de expressão musical:

\footnotetext{
Passados uns tempos, a Bianca, minha filha que toca piano, me disse: "Eu só queria um disco da Madonna." "Mas da Madonna?"; "É. Da Madonna". Eu não gostava nada da Madonna; comprei o disco. Ela pediu mais um, e depois outro. Até que um belo dia está minha filha sentada, feliz como o diabo. E eu feliz como o diabo pela felicidade dela. E o disco da Madonna tocando. Aí entendi que não tem música nem músicos que eu possa julgar. Tem música, ou músicos de que eu preciso para viver. A partir desse dia, qualquer discriminação que eu tinha acabou (Depoimento de Gismonti a AMARAL, 2007).
}

A improvisação entrou na carreira de um dos nossos maiores multi-instrumentistas de maneira inusitada quando, durante uma excursão no EUA, o percussionista Airto Moreira, repentinamente, deixou Gismonti sozinho no palco, que diz: "...sem partitura, sem ensaios, sem saber o que fazer. Era tocar de improviso ou sair correndo. Toquei e deu [um] estalo, numa emoção pura que nunca tinha sentido."
(CRYSÓSTOMO, 1976, p.119). Mas foi após sua experiência de várias semanas, em 1977, entre os Yawalapiti da Amazônia, a tribo do índio Sapain, que a música de Gismonti se tornou "... mais espontânea e ele passou a se preocupar com a busca de uma integração entre o músico, a música e o instrumento." (McGOWAN e PESSANHA, 1991, p.158).

Embora se refira ao sentido mais geral da trajetória de Gismonti, a reflexão de GODOY (2000, p.60-61) sobre a postura do músico experiente se organizando frente ao inusitado ou novo pode também ser estendida ao universo mais localizado de suas performances. Quando Gismonti relata, a partir de sua experiência de ser convidado a entrar na oca sagrada dos índios do Xingu, que "... 'Embora não existissem portas, paredes ou grades... o primeiro passo era ver o limite... cujo espaço interior muito reduzido... vivências intensas... componentes direcionais, dimensionais, componentes de passagem ou de fugas... se faziam simultâneos ou se misturavam..." (Depoimento de Gismonti a Carlos FREGTMAN, 1989, p.32). Recorrendo à sua fala, fazemos uma analogia para preparar nossa análise da realização de Frevo, em que Gismonti parece "ver o limite" de sua expressão musical a partir do "espaço interior muito reduzido" do material temático sucinto que escolhe, mas que lhe permite "vivências intensas" pela forma com que organiza, em tempo real, seus "componentes", que "se fazem simultâneos ou se misturam".

Egberto Gismonti é um músico com vasta produção. Nos 17 anos que separam seu primeiro disco - Egberto Gismonti de 1969 e o disco Alma de 1987 (GISMONTI, 1987a), ele lançou uma media de mais de dois discos por ano. Em relação ao disco Alma, seu conteúdo enfatiza o piano (mas com intervenções de instrumentos de teclado eletrônicos em diversas faixas) em uma atmosfera bastante intimista, dentro da linguagem tonal. Entretanto, pode-se observar que o recurso da fragmentação melódica - uma clara herança do pontilhismo erudito do século XX (de Webern ou Varèse) - é recorrente no disco, e fundamental no discurso de Frevo. Oito anos depois de lançar Frevo, Egberto revisita o gênero pernambucano e compõe Sonhos do Recife em 1995, obra analisada por SILVA (2005).

\section{3 - Análise formal, motívica e harmônica de Frevo}

Embora frevos geralmente sejam escritos no típico compasso binário 2/4 das marchas militares, podem ocasionalmente aparecem em compasso 4/4, como é o caso de Frevo. Entretanto, embora Egberto Gismonti tenha anotado Frevo em compasso quaternário (talvez para facilitar a escrita), percebe-se, pelas suas acentuações, que sua realização é binária.

Devido à sua natureza improvisatória, a versão de Frevo tocada por Gismonti no disco Alma (cuja partitura é apresentada às p.125-144, desse número de Per Musi) parece se encaixar no conceito da forma rapsódica de SCHOENBERG (2004, p.198), pois 
... sugere uma improvisação... [com seu ] seu inspirado imediatismo e vivacidade [mais do que ]... elaboração...mais pelo exercício da imaginação e emoção do que, propriamente, das faculdades estritamente intelectuais... abundância de temas e ideias contrastantes ... "pontes"...justaposições abruptas...

Em que pese apropriações mais recentes do jazz no choro, SÁ (2000, p.66-70) fala de características que diferenciam o improviso na linguagem tradicional desse gênero popular brasileiro do improviso no gênero norteamericano:

\section{Pegando seu Bandolim Joel [Nascimento] tocou cerca de cinco vezes o 'Ingênuo' praticamente sem alterar uma nota sequer, mas modificando todas as divisões rítmicas... [ao contrário do jazzista] 0 chorão, por sua vez, manifesta sua capacidade improvisadora fundamentada muito mais na melodia do choro que está interpretando, sendo a harmonia mais um decurso do que propriamente a ideia central ao redor da qual seria realizado um improviso... dar a ele próprio o direito de contribuir simplesmente com alguns ornamentos... [há também] 0 'molho'... através de uma mudança de métrica melódica... antecipa ou adianta uma nota ou um grupo de notas... não existe um improviso nascido de divagações... mordentes, glissandos, apojaturas, grupetos, entre outros, se dá de forma imprevisivel... numa espécie de interstício entre improviso e variação melódica... Trata-se, por conseguinte, de uma variação melódica.}

Podemos observar que se Gismonti recorreu à prática do jazz de realizar diversos choruses nessa versão de Frevo, por outro lado preferiu valorizar as características improvisatórias mais afins como aquelas descritas acima para o choro tradicional: alterações rítmicas (por antecipação, retardo, diminuição, aumentação, fragmentação), variações melódicas, espacialização de alturas, o "molho" pela adição e exclusão de notas, ornamentos, sem "divagações" que o levassem para fora do universo temático de poucos motivos com que constrói a obra.

Gismonti constrói essa versão de Frevo (inclusive os trechos improvisados, o que a deixa com um total de 352 compassos) com base em apenas cinco motivos temáticos (Motivos $\boldsymbol{a}, \boldsymbol{b}, \boldsymbol{c}, \boldsymbol{d}$, e; veja Ex.8) e nas recorrências de suas transformações (Ex.8). Quatro desses cinco motivos ocorrem já nos primeiros 14 compassos, cinco deles são apresentados na Seção I e o último aparece no início da Ponte (c.66). 0 Motivo a (c.1), em arco, é caracterizado por um arpejo descendente em semínimas finalizado com síncope de colcheia em grau conjunto ascendente. 0 Motivo $\boldsymbol{b}$ (c.9), também em arco, sobem com um arpejo e depois desce em graus conjuntos. 0 Motivo c (c.11) tem um contorno melódico entrecortado de colcheias, cuja direção final é descendente. 0 Motivo $\boldsymbol{d}$ (c.14) é o ritmo de quiálteras de três notas, representa a sugestão de métrica ternária no ambiente binário do frevo. 0 Motivo e, o único que não aparece no início da peça, é um ostinato de colcheias seguidas (c.66 da Ponte).

Recorrendo ao desenvolvimento desses materiais temáticos, Gismonti faz com que a forma final de Frevo corresponda a uma forma expandida da canção tradicional (Ex.8 e Ex.9), própria do gênero frevo, com uma Ponte entre a Seção I e a Seção II e uma Coda. A Seção $I$, por si só, é estruturada como uma pequena forma canção dentro da forma canção maior, sendo composta da Subseção $A$ (repetida com variações como Subseção $A^{1}$ ), Subseção $B$ seguida da Subseção $A^{2}$. A Ponte não apresenta subseções. A Seção II é formada pela Subseção $C$, Subseção $D$ e Subseção $B^{1}$

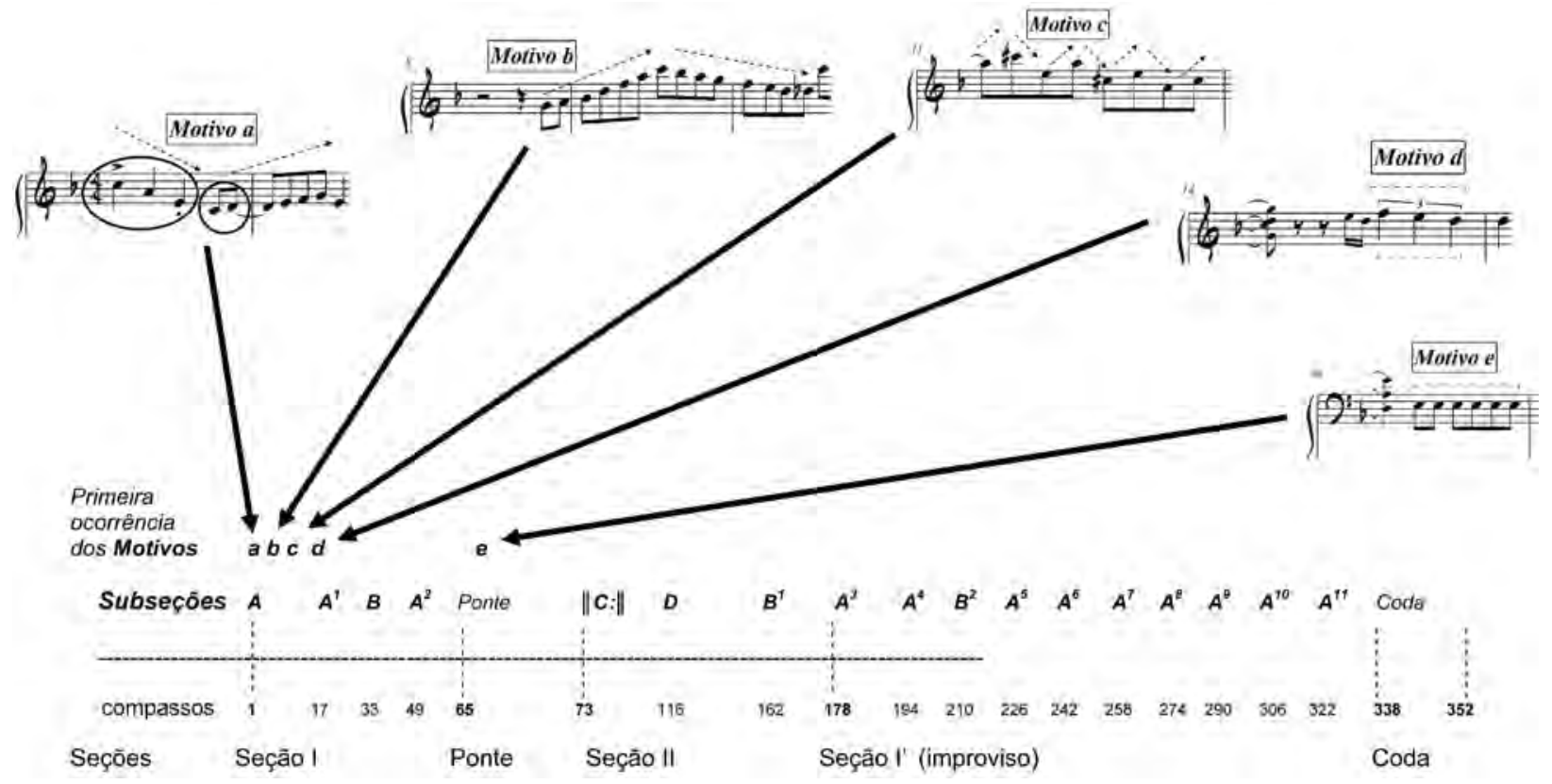

Ex.8- Esquema formal de Frevo (composição e performance de Egberto GISMONTI, 1987a no disco Alma) com seções, subseções e motivos temáticos geradores da obra (Motivos $a, b, c, d, e)$ com a indicação de suas primeiras ocorrências na obra (veja o Ex.9 para ocorrência dos Motivos temáticos em toda a obra). 


\begin{tabular}{|c|c|c|c|c|c|}
\cline { 2 - 6 } \multicolumn{1}{c|}{} & Subseção & Motivo temático & $\begin{array}{c}\text { No de } \\
\text { compassos } \\
\text { (total de } \\
352 c \text {.) }\end{array}$ & $\begin{array}{c}\text { Localização da subseção } \\
\text { na partitura } \\
\text { (compasso) }\end{array}$ & $\begin{array}{c}\text { Localização da subseção } \\
\text { na gravação } \\
\text { (minutos e segundos) }\end{array}$ \\
\hline \multirow{5}{*}{ SEÇÃO I } & $A$ & $a, b, c, d$ & 16 & $c .1$ & {$[00: 00]$} \\
\cline { 2 - 6 } & $A^{1}$ & $a, b, c, d$ & 16 & $c .17$ & {$[00: 16]$} \\
\cline { 2 - 6 } & $B$ & $d, c$ & 16 & $c .33$ & {$[00: 31]$} \\
\hline
\end{tabular}

\begin{tabular}{|c|c|c|c|c|c|}
\hline PONTE & Ponte & $a, e$ & 8 & c. 65 & [01:02] \\
\hline \multirow{3}{*}{ SEÇÃO II } & $C:$ & $a, e, b, c$ & $43(23+20)$ & c.73 & [01:10] \\
\hline & $D$ & $a, c, e$ & 46 & c. 116 & [01:52] \\
\hline & $B^{1}$ & $d, c$ & 16 & c. 162 & [02:38] \\
\hline
\end{tabular}

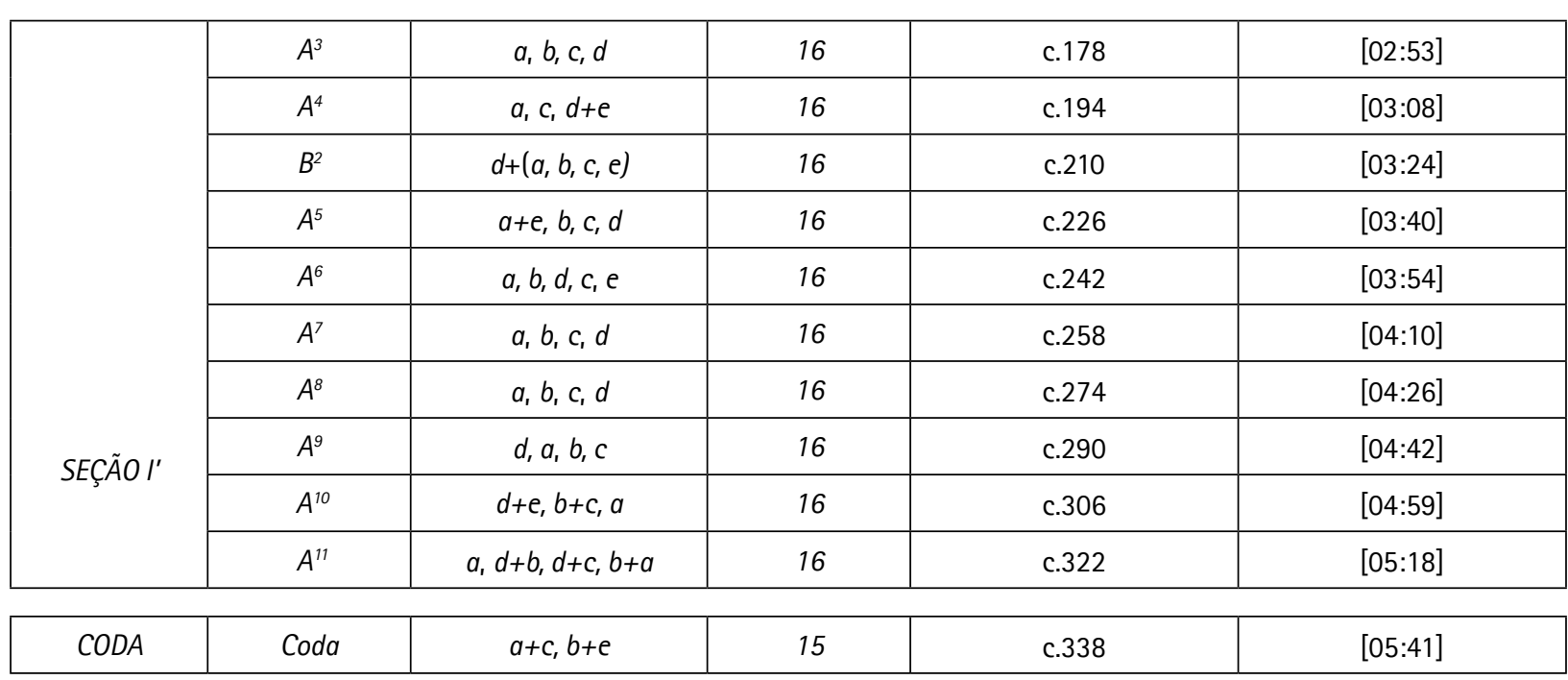

Ex.9 - Quadro com ocorrências dos motivos temáticos (Motivos $a, b, c, d$, e) e suas combinações nas seções e subseções de Frevo de Egberto Gismonti, com sua localização de compassos na partitura transcrita (veja às p.125-144) e de timing na gravação no disco Alma (GISMONTI, 1987a).

(que é uma variação da Subseção $B$, trazendo de volta materiais da Seção I). A Seção I', que fecha a grande forma ternária, é uma grande expansão da Seção $I$, cujas subseções são variações de subseções anteriores, em um processo improvisatório que gerou as seguintes subseções formais: as Subseções $A^{3}$ e $A^{4}$ seguidas pela Subseção $B^{2}$ que é seguida por uma longa justaposição de variações formada pelas Subseções $A^{5}, A^{6}, A^{7}, A^{8}$, $A^{9}, A^{10}$ e $A^{11}$. A obra é finalizada com uma Coda, na qual Gismonti volta a reutilizar motivos temáticos apresentados anteriormente nas várias seções de Frevo. Assim, ao mesmo tempo em que ainda se atém a um padrão formal estruturado e planejado, Gismonti também reserva ao Frevo uma atmosfera de liberdade, ao estender as seções formais por justaposição de seções improvisadas, ao combinar e recombinar sem uma ordem lógica os motivos temáticos, o que acrescenta ao frenesi frevístico, a sensação de caos.
Das 19 subseções de Frevo (veja Ex.9 acima), o Motivo c participa de 17 subseções, o Motivo a de 16 subseções, 0 Motivo $\boldsymbol{d}$ de 15 subseções, o Motivo $\boldsymbol{b}$ de 14 subseções, e o Motivo e de 9 subseções. Esse grande número de recorrências de cada motivo mostra um alto grau de unificação temática da obra. A predominância do Motivo c com seu contorno melódico entrecortado (também sugerido na gradual espacialização dos motivos para os registros extremos), permeando toda a peça, confere o caráter de agitação típica do gênero. Contribui para essa atmosfera de aparente caos o fato da recorrência e combinação dos motivos dentro das subseções ser aleatória: nem sempre recorrem e nem sempre aparecem na mesma ordem. Entretanto, o fato de todas as subseções serem iniciadas pelo Motivo a $\left(A, A^{1}, A^{2}\right.$, Ponte, $C, D, A^{3}, A^{4}, A^{5}, A^{6}, A^{7}, A^{8}$, $A^{11}$, Coda) ou Motivo $d\left(B, B^{1}, B^{2}, A^{9}, A^{10}\right)$ traz ao ouvinte a familiaridade de retornar formalmente a algo ouvido antes, redundância é muito comum - talvez essencial - à 
compreensão musical, especialmente na música popular. Assim, o contraste principal entre as subseções ocorre quando a textura eminentemente contrapontística a duas vozes da obra dá lugar à homofonia dos blocos de acordes pesados da Ponte, ou aos pedais repetitivos da Subseção C, ou à melodia de bicordes acompanhada por acordes cantabile da Subseção D.

Harmonicamente, em relação às macro estruturas, Egberto organiza Frevo em torno de um único centro tonal, Ré menor (com algumas implicações modais), que permeia todas as Seções, respectivas Subseções, Ponte e Coda. Para gerar algum contraste harmônico, ele utiliza apenas dois recursos: (1) as diferenças entre tonalidade e modalidade, ou seja, Ré Menor (com a presença do Dó \# como sensível), Ré Dórico (com a presença dos graus $\mathrm{Si}$ natural-Dó natural) e Ré Eólio (com a presença dos graus Si bemol-Dó natural); (2) as substituições harmônicas observadas nos c.131-133 e c.151-153 da Subseção D da Seção II. Gismonti estrutura o Frevo principalmente com a perspectiva polifônica, o que gera certa ambiguidade em relação às progressões harmônicas. 0 Ex.10 mostra uma explicação da possível harmonia da Subseção $A$ (c.1-16) que abre a obra. Polifonicamente, uma redução das mãos direita e esquerda do piano nesse trecho inicial mostra a simplicidade de fundamentais no baixo descendente.

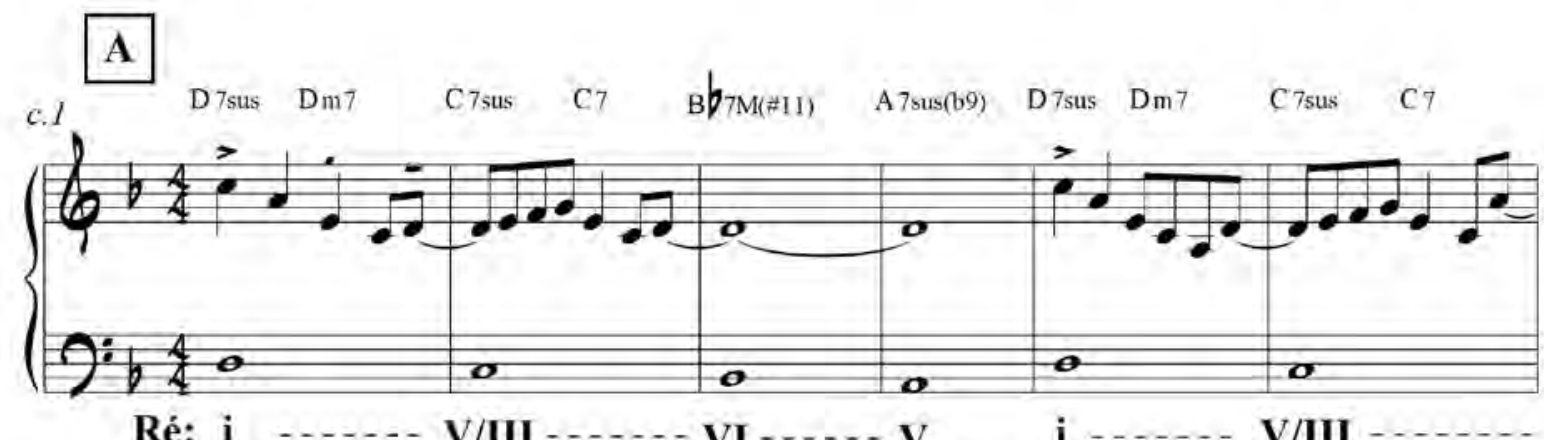

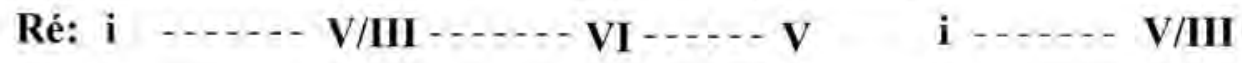
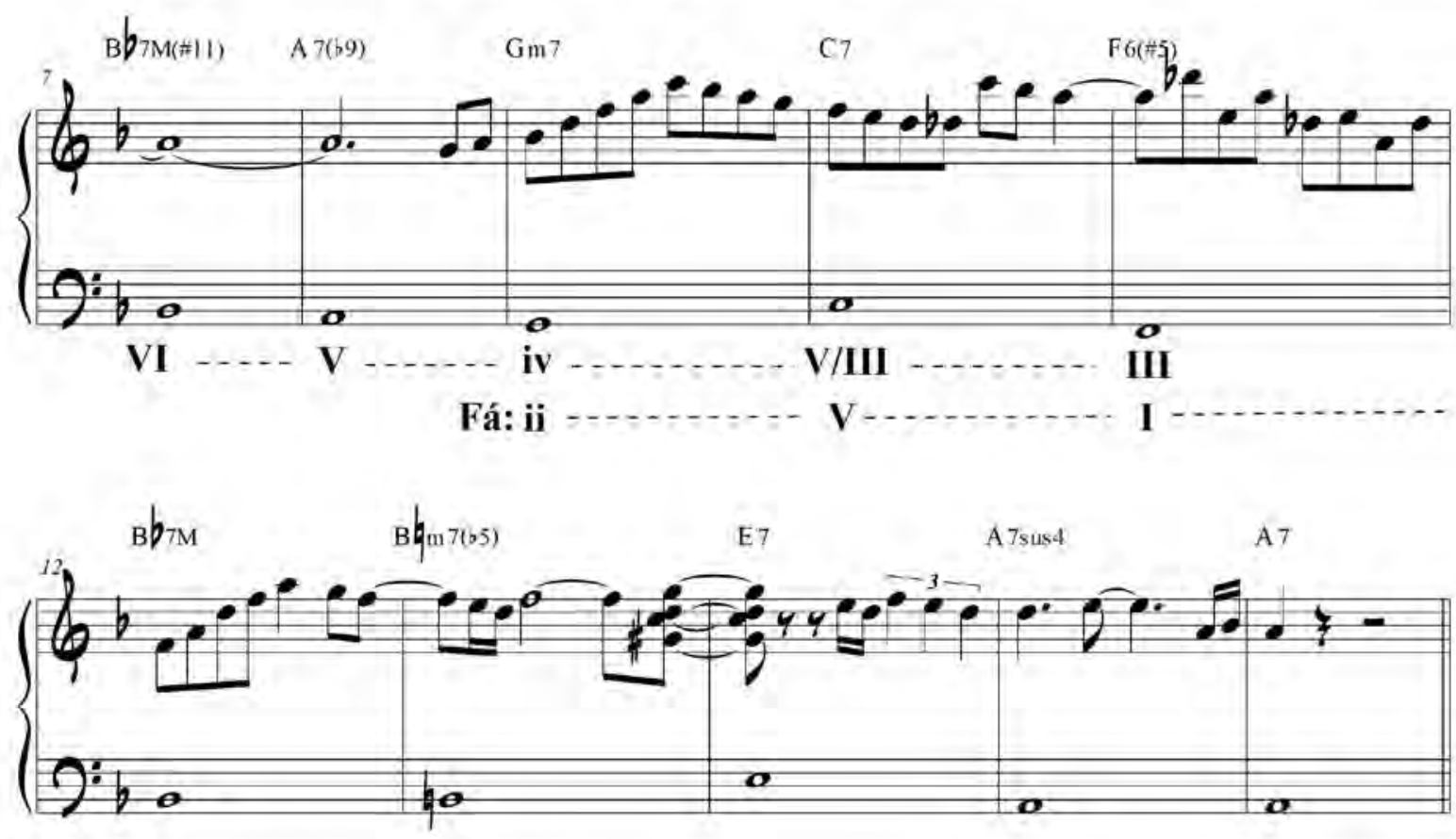

Fá: … IV …..... viiio/V

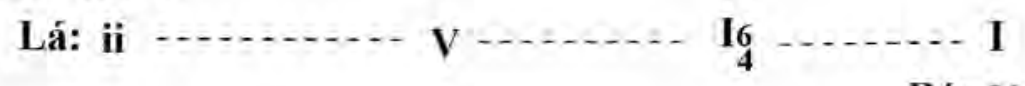

Ré: V

Ex.10 - Progressão harmônica da Subseção $A$ (c.1-16), com simplificação da mão esquerda e possiveis acordes (completos, mas com análise simplificada das funções). 

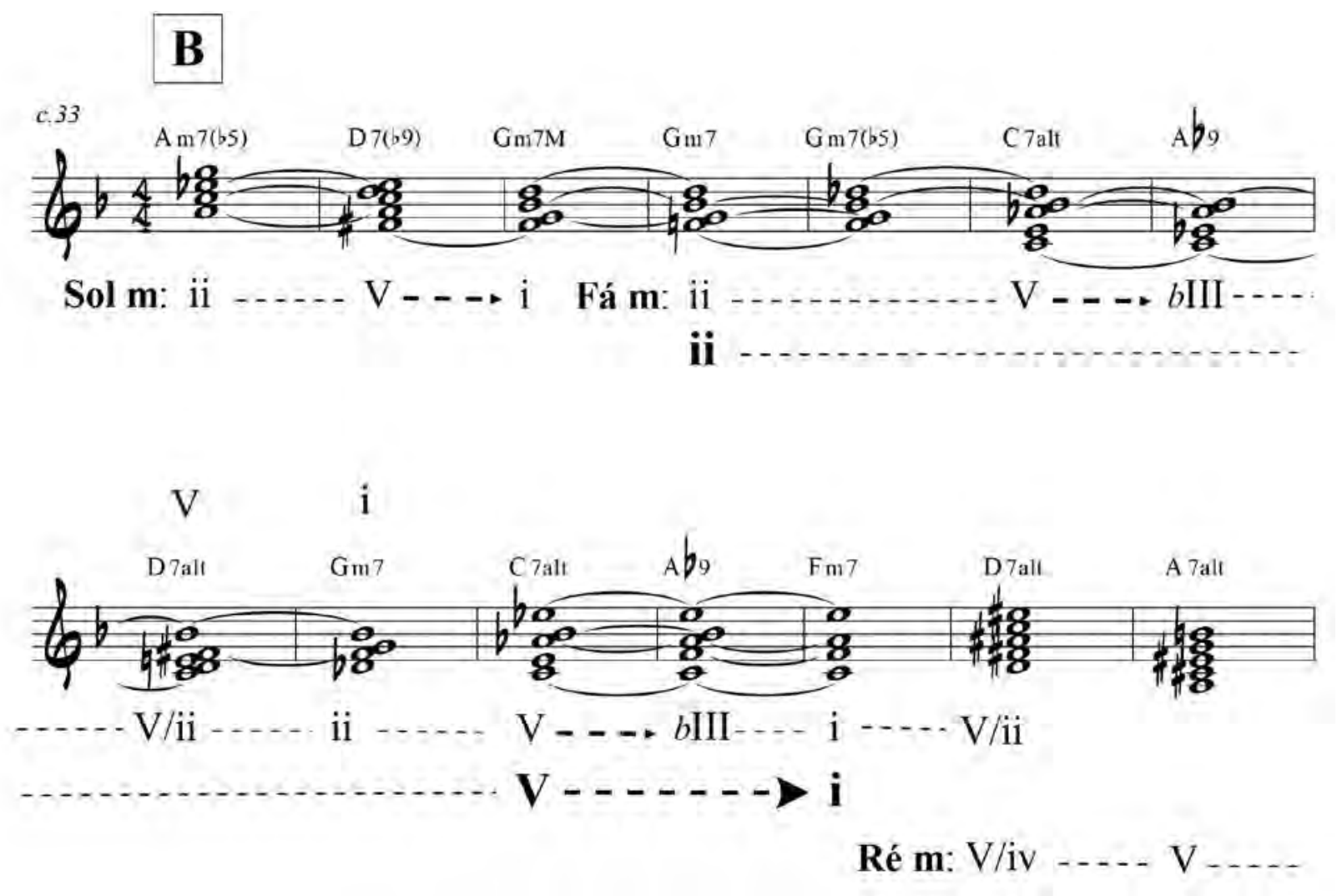

Ex.11 - Redução harmônica (com análise simplificada das funções) da Subseção $B$ de Frevo, na qual Gismonti utiliza notas comuns entre os acordes para gerar, gradualmente, tensão e relaxamento.

A redução harmônica da Subseção $B$ (c.33-48) mostra como Gismonti utiliza o recurso de notas comuns para estabelecer uma progressão sem grandes contrastes dentro do mesmo centro de Ré menor criando tensão gradualmente e retardando sua resolução (Ex.11). A presença das notas Fá e Fá \# não acena para a mistura modal maior-menor, mas sim para a utilização de dominantes secundárias. Ao mesmo tempo, essas notas parecem sugerir uma característica da escala do blues.

Na Ponte, Gismonti sugere a alternância entre as escalas de Ré Frígio e Ré Dórico nos blocos de acordes paralelos dos c.65-72. Se na Subseção A Gismonti havia empregado o centro modal de Ré Eólio, ele utiliza Ré Dórico em toda a extensão da Subseção $\boldsymbol{C}$ (c.73-115). Ali, a harmonia de base é definida pela linha melódica de caráter improvisatório da mão direita, preparada por um riff na mão direita e por um pedal com a síncope do Motivo a na mão esquerda, que enfatiza a tônica Ré e percorre toda essa subseção. Assim, fica evidente que o compositor escolheu o modo $\mathrm{D}$ dórico como forma de unificar o início da obra com as seções seguintes.

A Subseção $D$ (c.116-163) segue um esquema muito parecido com o da Subseção $A$, com uma linha de baixo descendente, mas centrada em Ré Dórico e com as harmonias apresentadas com antecipações de colcheias.
Ainda nesta subseção ocorrem dois raros trechos de substituição harmônica de Egberto em todo o Frevo. Nos c.132-133 (e depois repetido nos c. 152-153), ele substitui os esperados acordes de Dm7- G7 de C7sus4 (ou seja, ii7 - V7 da subtônica Dó) pelo equivalente um trítono acima, gerando a seguinte progressão: $\mathrm{G \# m7(b5)}$ - Db7(b9) - C7sus4, como mostra o Ex.12.

Outro procedimento que permite a Gismonti se afastar um pouco do idioma predominantemente diatônico de Frevo é uma utilização criativa e mais livre de notas não harmônicas (antecipações, notas de passagem, bordaduras etc.) que soam como aproximações harmônicas utilizadas na improvisação jazzística. 0 Ex.13 mostra como os materiais da Subseção $\boldsymbol{B}$ (c.33; Ex.13a) gradualmente se tornam mais dissonantes nas Subseções $B 1$ (c.162; Ex.13b) e B2 (c.210; Ex.13c) sem que ele recorra a um afastamento do centro harmônico.

\section{4 - 0 Desenvolvimento temático de Egberto Gismonti em Frevo}

Do ponto de vista do fraseado, Gismonti tende a seguir a quadratura que se estabeleceu no período clássico, e que se tornou típica na maioria dos gêneros populares: quase todas as subseções de Frevo (15 do total de 19) são construidas com frases 16 compassos cada uma 


\section{D}
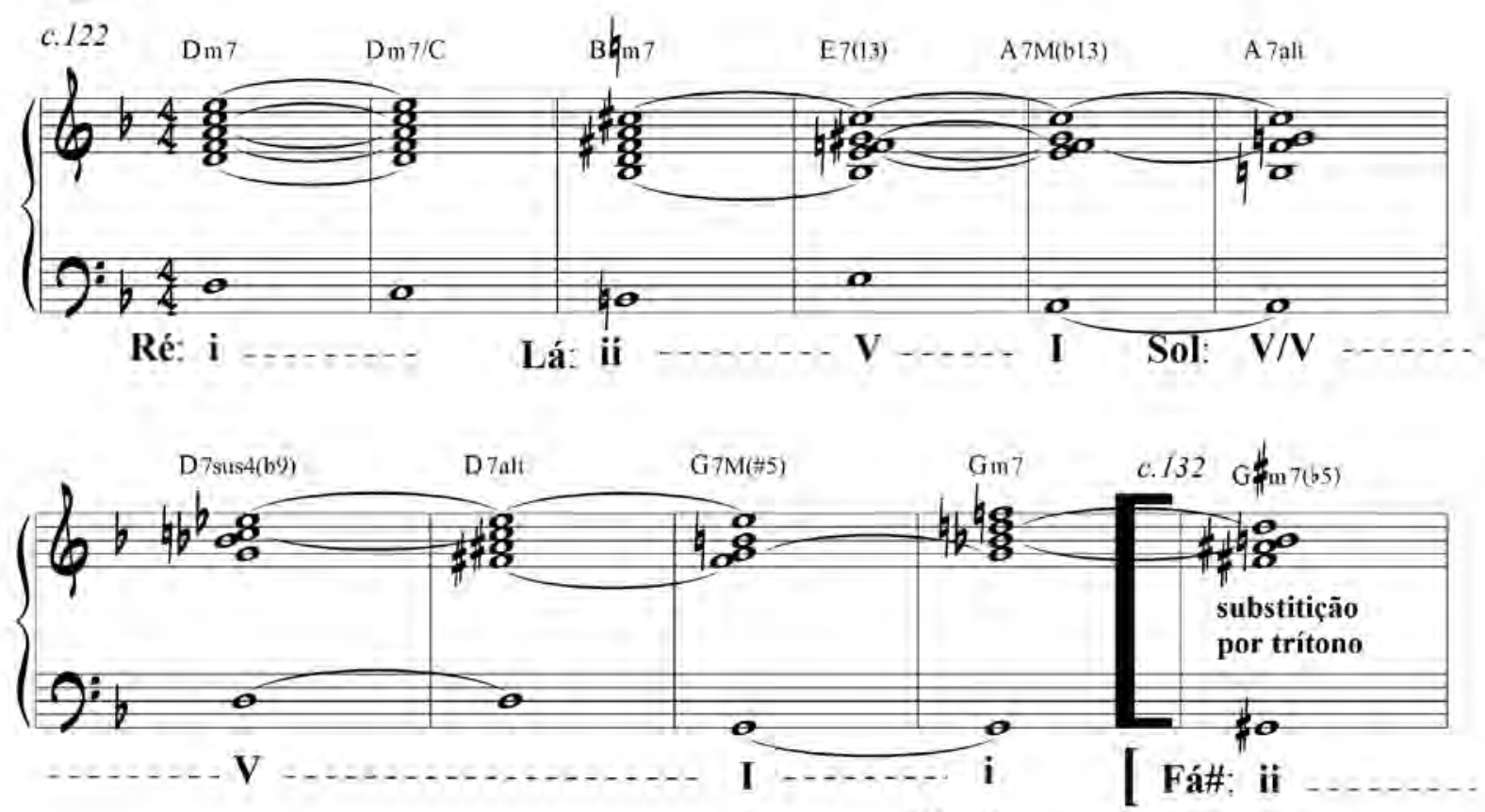

Fá: ii

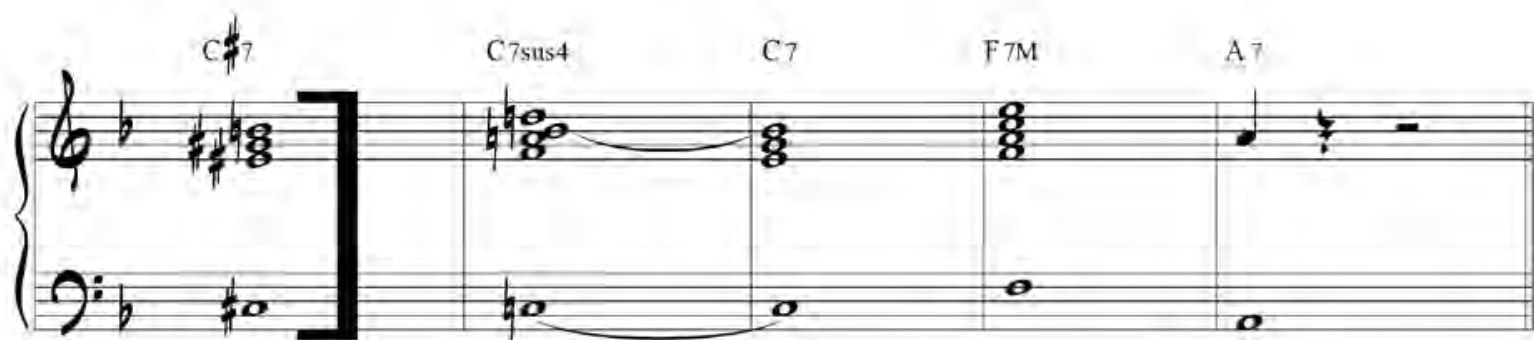

Fá\#: …… V

Fá:

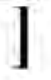

Ré: V

\section{I}

Ex.12 - Um dos raros trechos de Frevo (parte da Subseção D) em que Gismonti recorre a uma substituição de acordes mais jazzistica (com análise simplificada das funções).

(veja Ex.9 acima). Entretanto, a previsibilidade que esta fraseologia supõe é evitada - e dai a sugestão proposital do caos festivo-agressivo e contrapontístico do gênero frevo em ambas as música e dança - pela maneira como Gismonti varia as recorrências dos motivos, frases, seções e subseções. A repetição, transformação e reorganização dos motivos, também uma herança da Primeira Escola de Viena (que teve em J. Haydn e Beethoven expoentes desse procedimento) é feita com a liberdade improvisatória com que SCHOENBERG $(1994,2006)$ caracteriza seu conceito de variação progressiva (developing variation). Assim, podem ser observadas manipulações envolvendo reharmonização, apresentação $a$ capella, fragmentação, diminuição, aumentação, inversão, espacialização, superposição, justaposição, combinação e recombinação dos materiais temáticos.
0 Motivo $a$, por exemplo, o mais memorável porque marca o início de 14 das 19 subseções de Frevo, sofre manipulações sutis entre sua primeira aparição, na Subseção $A$ (c.1; Ex.14a), e sua recapitulação. Primeiro na Subseção $A^{1}$ (c.17; Ex.14b), com modificações rítmicas, omissão de notas, mudança de registros. Depois, o Motivo $a$ é novamente recapitulado na Subseção $A^{2}$ (c.49; Ex.14c), que volta a ficar mais densa com a adição de notas e de novos ritmos (como a semicolcheia e a quiáltera de 3 colcheias). Como se pode perceber, o estilo improvisatório de Gismonti no Frevo é muito mais próximo do padrão de improvisação brasileiro do choro - mais focado nas variações rítmicas e ornamentais $(S \dot{A}, 2000)$ - do que das práticas de performance do jazz, que é mais orientada pela harmonia, com uma invenção melódica mais distante dos materiais temáticos. 

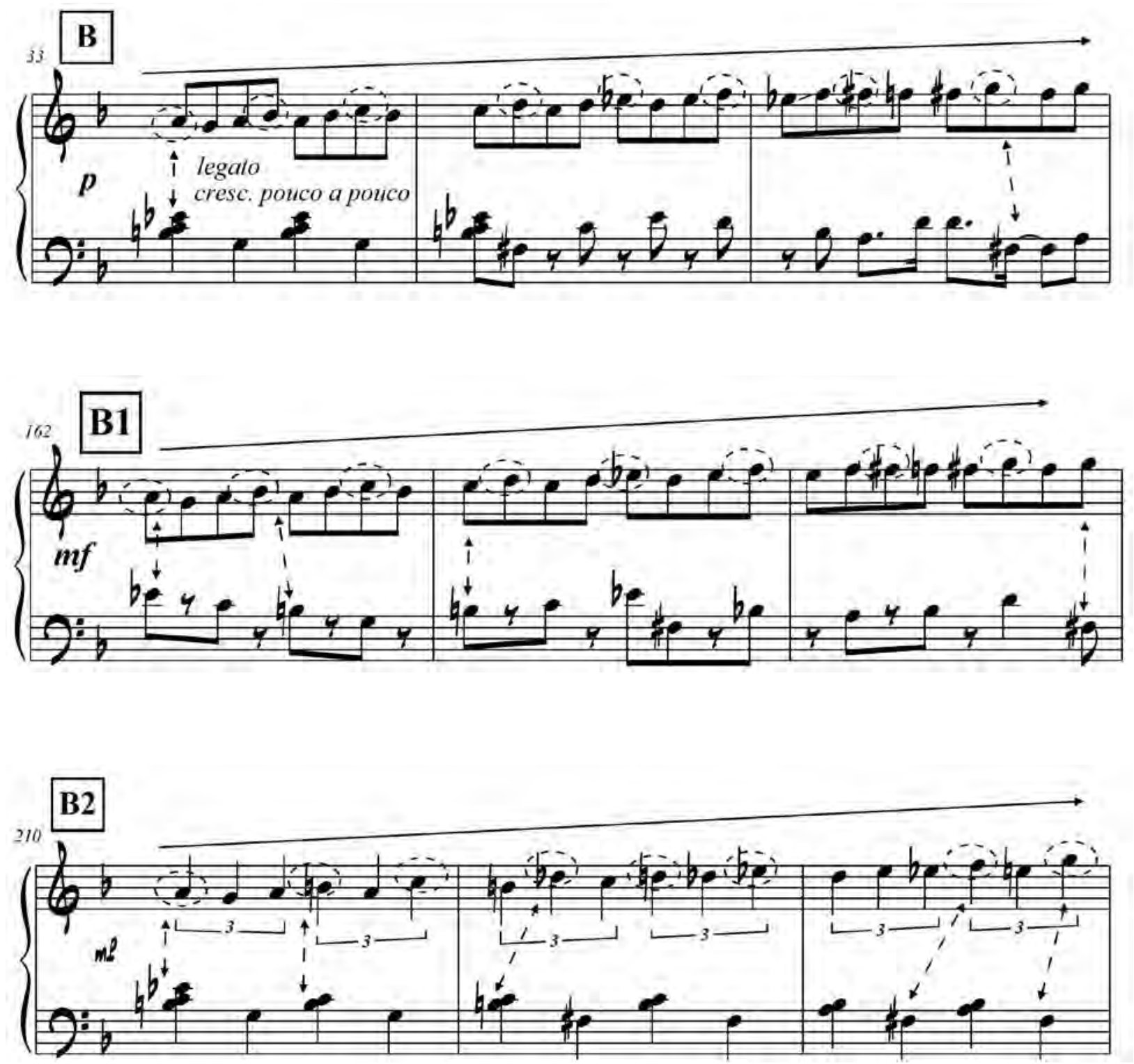

Ex.13a, b, c - Utilização crescente de dissonâncias não funcionais por Egberto Gismonti nas Subseções $\boldsymbol{B}, \boldsymbol{B} 1$ e $\boldsymbol{B} 2$ de Frevo.

Os motivos de Frevo também podem sofrer fragmentação seguida de transformações desses fragmentos. A parte descendente do Motivo a, por exemplo, é manipulada de diversas formas: por alteração rítmica (c.65; Ex.15a), por diminuição por colcheias repetidas (c.119; Ex.15b), por sincopação (c.168; Ex.15c), por deslocamento das semínimas (c.338; veja Ex.23, mais abaixo).

Já a parte ascendente e final do Motivo a - sua síncope - é manipulada com deslocamento (c.15; Ex.16a), espacialização de registro (c.117; Ex.16b), uso de pedal que usa a estaticidade do Motivo e (c.73-115; Ex.16c) sequenciamento (c.200; Ex.16d), diminuição e sequenciamento (c.278; Ex.16e).
Essas partes do Motivo a podem ainda estar diminuídas e comprimidas (c.283; Ex.17a) ou imbricadas entre si (c.298; Ex.17b) ou com parte do Motivo $\boldsymbol{b}$ (inversão do trecho escalar) em processo de expansão (c.344-350; veja Ex.23, mais abaixo).

Como o Motivo a, o Motivo $\boldsymbol{b}$ é também fragmentado por Gismonti para ser desenvolvido tematicamente. Sua primeira parte, o arpejo ascendente, reaparece com diminuição por semicolcheias no sentido original (c.87; Ex.18a) ou invertido (c.94; Ex.18b), imbricado com a quiáltera do Motivo d (c.221; veja Ex.20d, mais abaixo), e com acordes quebrados (c.264; Ex.18c). 


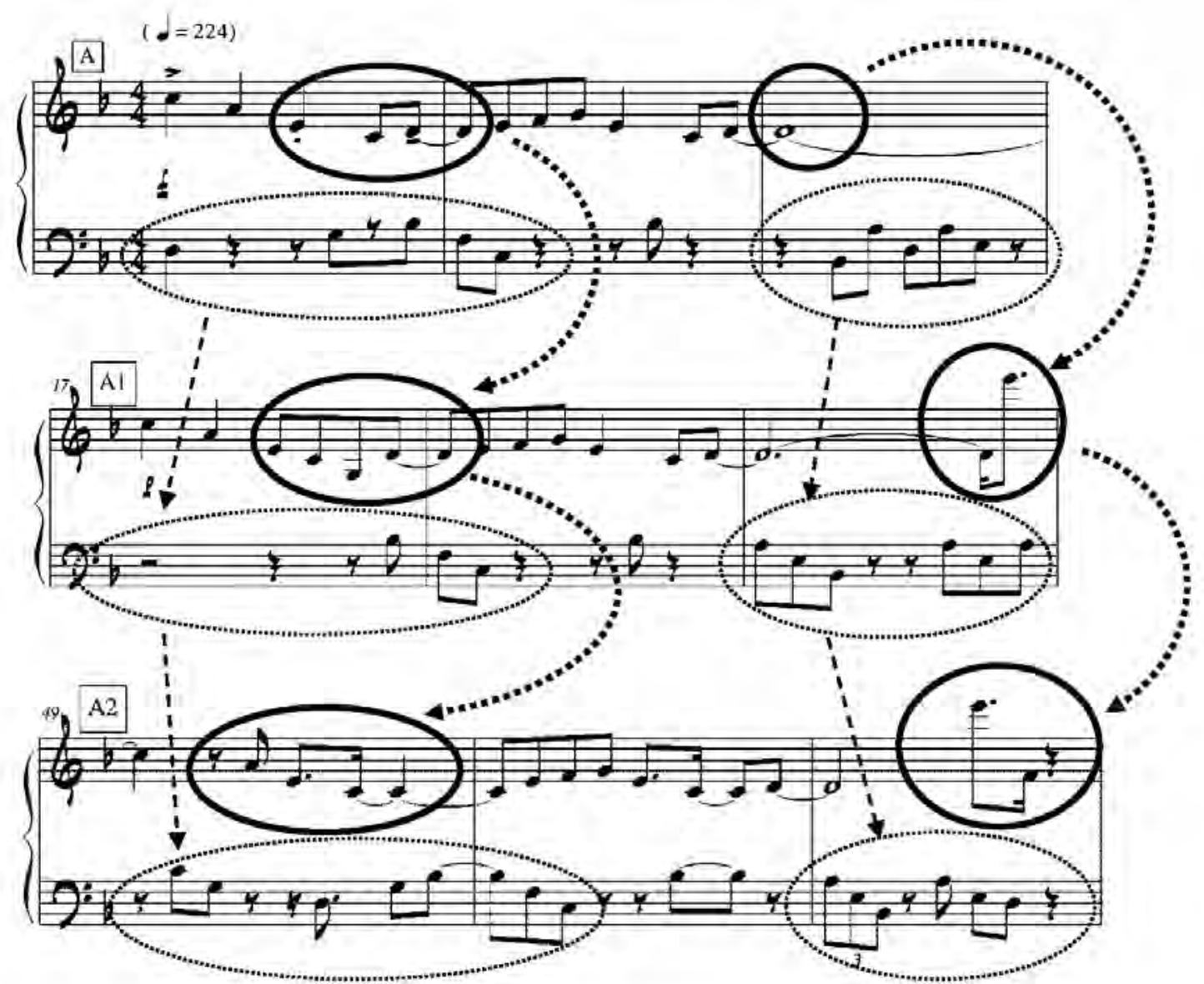

Ex.14a, b, c - pequenas variações do Motivo a de Frevo de Egberto Gismonti (Subseções $A_{1} A^{1}$ e $A^{2}$ ) por acréscimo e diminuição de notas e ritmos, rarefação da textura e inclusão de registro contrastante.
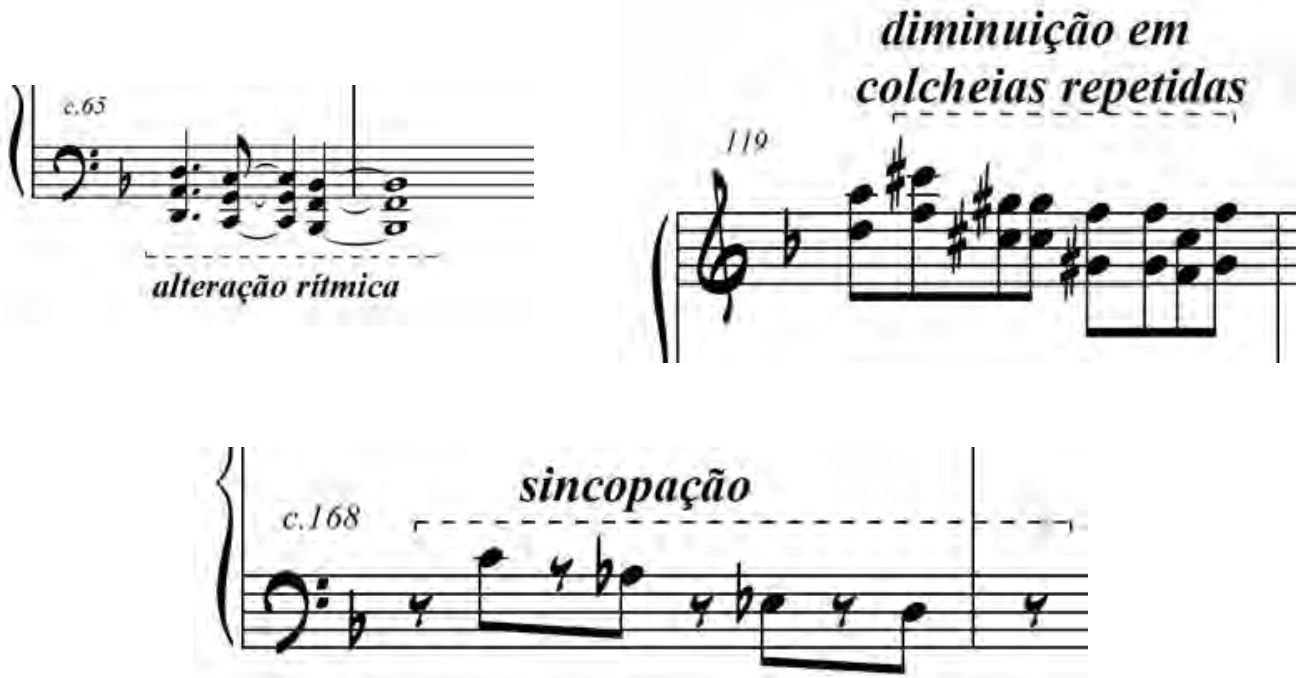

Ex.15a, b, c - Manipulações da primeira parte do Motivo a de Frevo de Egberto Gismonti. 

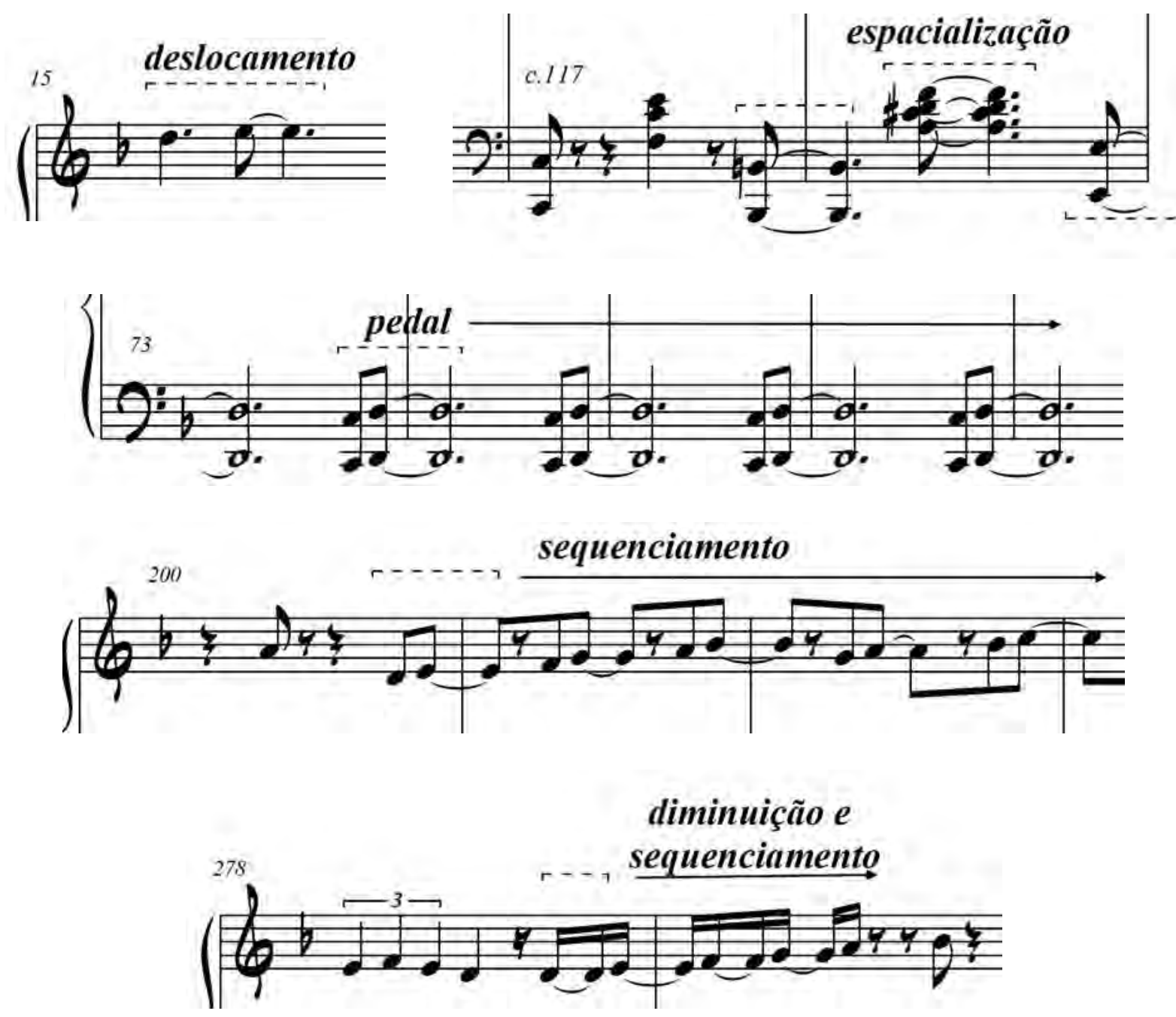

Ex.16a, b, c, d, e - Manipulações da segunda parte do Motivo a de Frevo de Egberto Gismonti.
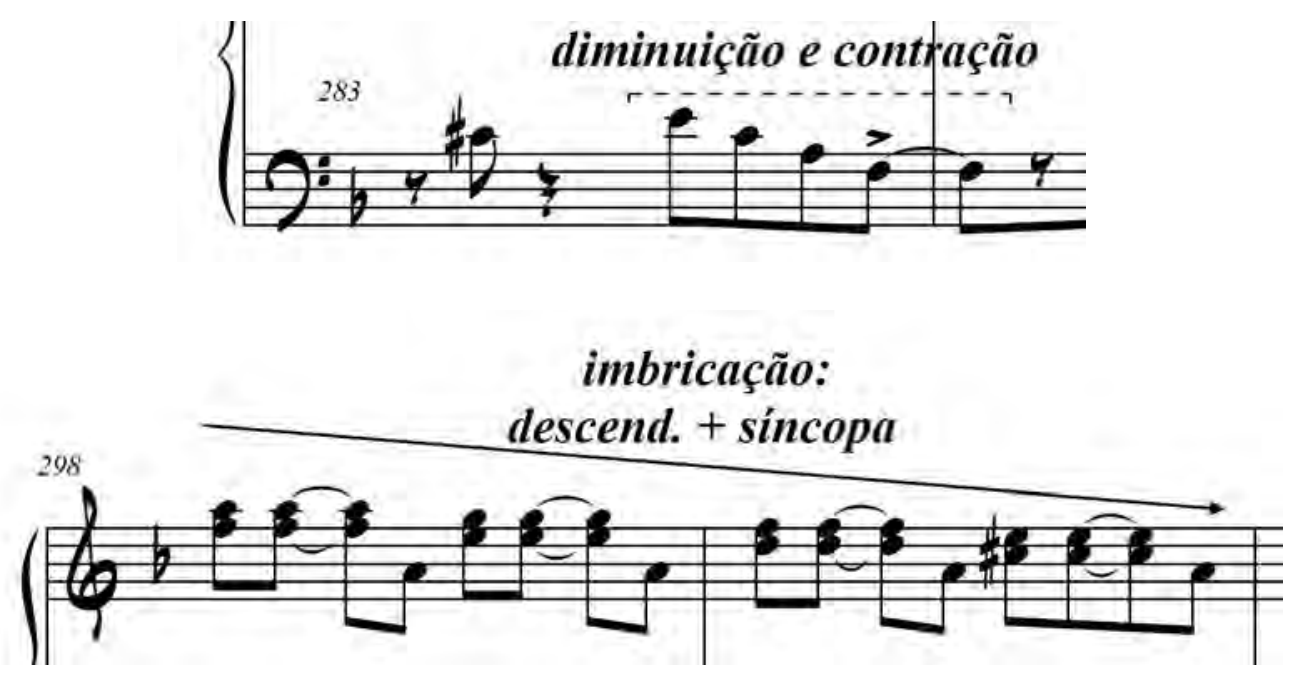

Ex.17a, b- Compressão e imbricação das partes do Motivo a do Frevo de Egberto Gismonti entre si. 

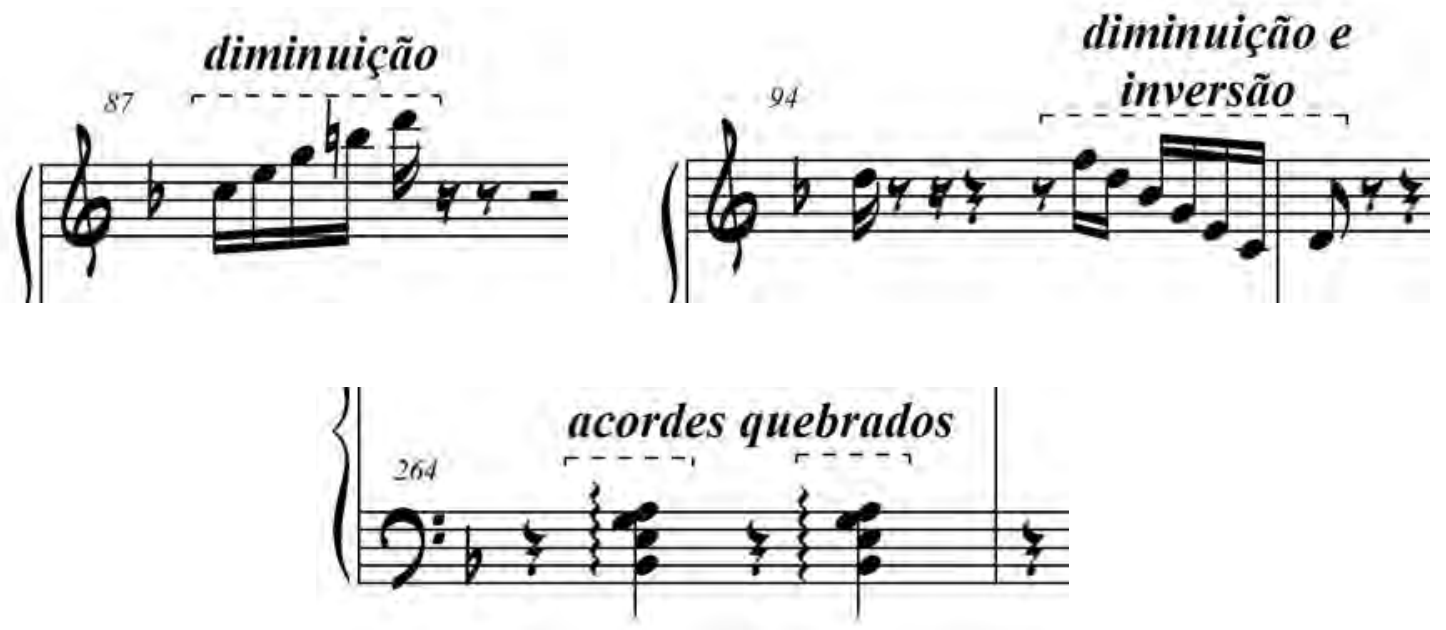

Ex.18a, b, c - Desenvolvimento temático do arpejo do Motivo b em Frevo de Egberto Gismonti.
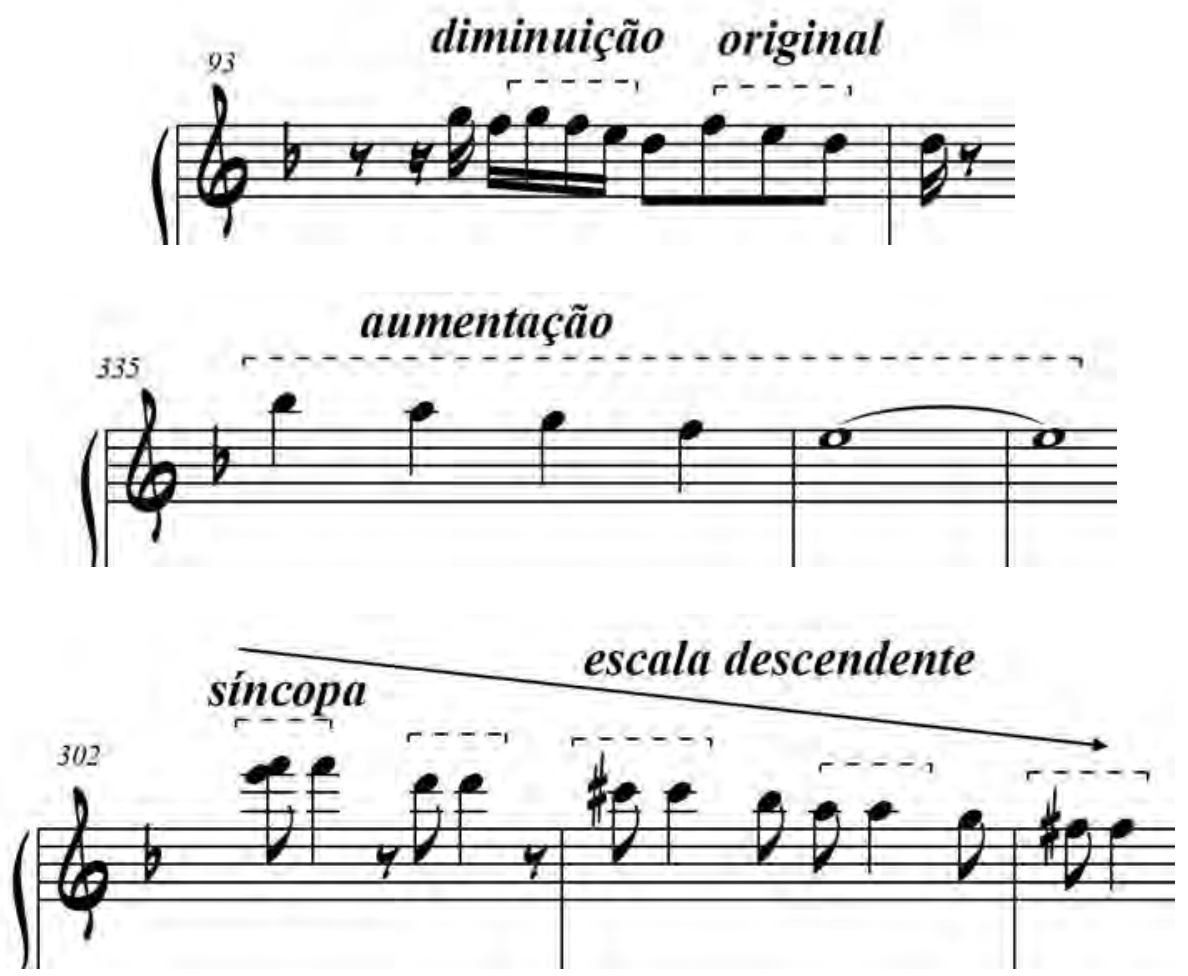

Ex.19a, b, c - Desenvolvimento temático do trecho escalar do Motivo b em Frevo de Egberto Gismonti.

Já a segunda parte do Motivo $\boldsymbol{b}$ - o trecho escalar descendente - é desenvolvido tematicamente com diminuição em semicolcheias (c.93; Ex.19a), na aumentação em semínimas e semibreves antes da Coda (c.335; Ex.19b), imbricado nas síncopes do Motivo a (c.302; Ex.19c; veja também o c.298 no Ex.17b, acima), imbricado com a redundância do Motivo e em notas repetidas (c.224; veja Ex.21c, mais abaixo), na diminuição de semicolcheias em longa sequência que lembra métodos de piano (c.231; veja Ex.1a, acima), e combinado aos Motivo a e Motivo e para finalizar o Frevo (c.344; veja Ex.23, mais abaixo).
Uma das sofisticações de Gismonti no Frevo é o desenvolvimento temático do ritmo, especialmente na sugestão de uma métrica complexa em que superpõe sugestões de ternário com binário (c.34; veja Ex.5, mais acima). A sugestão de métrica ternária, originada na quiáltera do Motivo $\boldsymbol{d}$ é desenvolvida de outras maneiras: tratada homofonicamente nas mãos direita e esquerda do piano (c.30; Ex.20a), com diminuição rítmica (c.193; Ex.20b), imbricada na estaticidade do Motivo e (c.205; Ex.20c), imbricada no arpejo ascendente do Motivo $\boldsymbol{b}$ e na linha entrecortada descendente do Motivo c (c.221; Ex.20d), espacializada do grave ao agudo do piano (c.329; Ex.20e). 

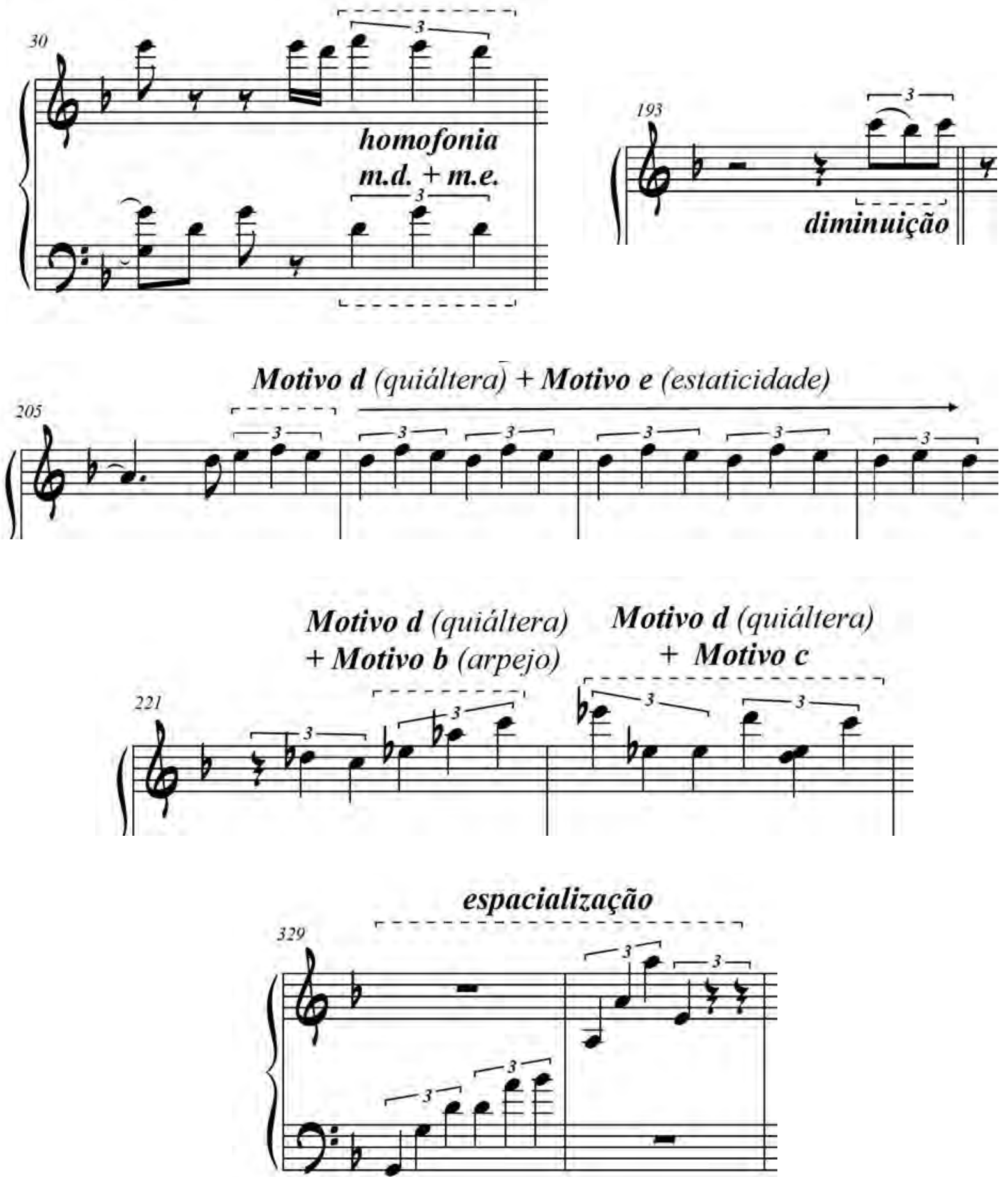

Ex.20a, b, c, d, e - Desenvolvimento temático das quiálteras do Motivo d em Frevo de Egberto Gismonti.

A estaticidade do ostinato do Motivo e é explorada tematicamente de diversas maneiras: na oscilação contínua (c.120; Ex.21a) ou fragmentada (c.117; Ex.21b) de bicordes na m.d. do piano, como pedal junto com a síncope do Motivo a que percorre toda a Subseção $C$ (c.73; veja Ex.16c, mais acima), transformado em trinado (c.81; veja Ex.1c, mais acima), na repetição do Motivo $\boldsymbol{d}$ (c.205; veja Ex.20c, logo acima), nos dobramentos de notas da escala descendente do Motivo $\boldsymbol{b}$ acompanhados por acordes repetidos (c.224; Ex.21c), na voz estacionária de melodias polifônicas (c.226; veja Ex.3b, mais acima), na imbricação com os Motivos a e $\boldsymbol{b}$ que termina a peça (c.344 em diante; veja Ex.23, mais abaixo).

Na Ponte que liga as Seções I e II, blocos de acordes em notas longas do Motivo a simplificado e tratado homofonicamente (c.65, 67, 69, 71; Ex.22) se alternam com recorrências do Motivo e (c.66, 68, 70; Ex.22). Já 

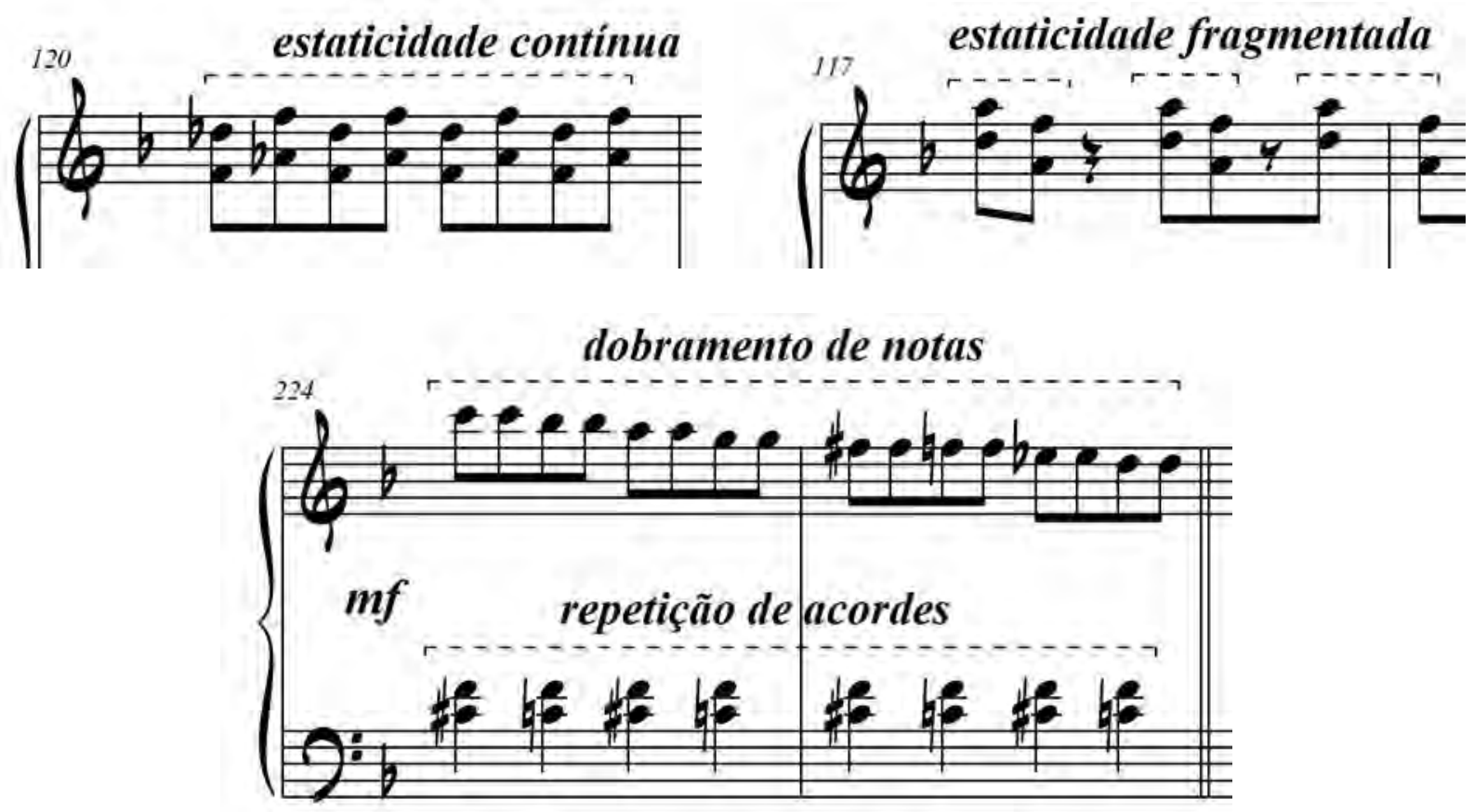

Ex.21a, b, c - Desenvolvimento temático da estaticidade do Motivo e em Frevo de Egberto Gismonti.

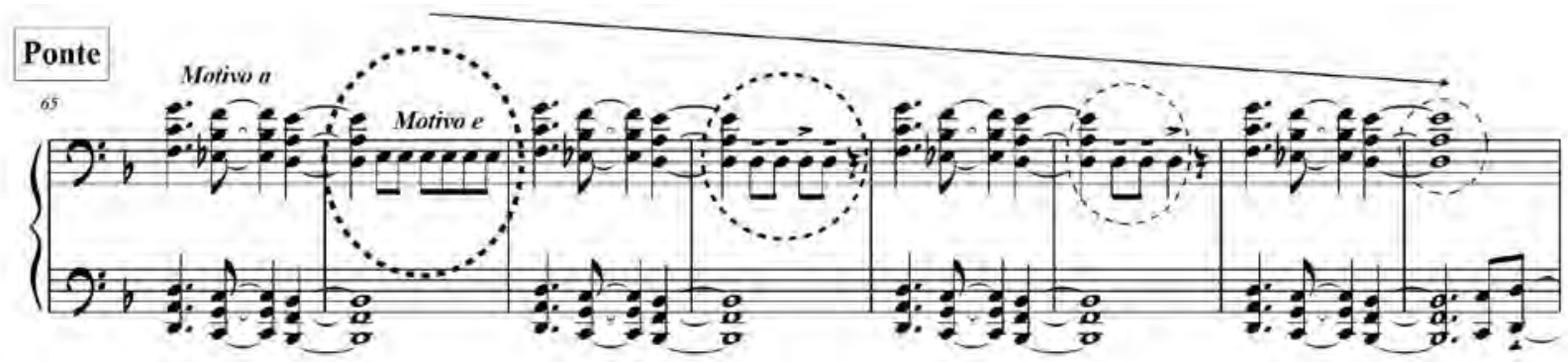

Ex.22 - Ponte de Frevo, na qual Gismonti utiliza os Motivo a e Motivo e com diminuição rítmica para preparar o início da Seção II.

o Motivo e, apesar de manter sua característica básica - a estaticidade e redundância -, entra em um processo de rarefação rítmica (de 6 colcheias para 4, para 2 e para nenhuma), como um pedal que vai se esvaindo. Como veremos adiante, Gismonti lança mão desse procedimento na Coda, para finalizar o Frevo, e evitar os finais apoteóticos típicos do gênero.

Uma das surpresas que Egberto apresenta no Frevo é não finalizá-lo com o esperado clímax dos frevos. A agitação do contraponto sincopado e um longo diminuendo gradualmente dão lugar à fragmentação e dispersão dos materiais temáticos que marcam o início em ppp da Coda (c.338; Ex.23). Como se fizesse alusão a um bloco de frevo que desaparece na distância (c.338-343), nas ruas de Olinda (terra de seu grande parceiro musical Naná
Vasconcelos), Gismonti alterna a estaticidade do Motivo e com a aumentação de mínimas e semínimas, com fragmentos do Motivo a (as semínimas descendentes e a síncope com aumentação de mínima (síncope aqui sugerida pelo tenuto no Ré do c.343). Depois, como um último aceno de foliões atrasados, remanescentes atrás do bloco, mas sem perder a verve (c.344 ao fim), Gismonti cria uma última inflexão musical antes do final, construída com um cresc. seguido de decres., sobre o qual fragmentos do Motivo a (a síncope - de fato ou novamente sugerida pelas ênfases nas notas-alvo, anotadas na partitura transcrita como tenuto), do Motivo $\boldsymbol{b}$ (inversão dos trechos escalares descendentes, cada vez mais longos) e do Motivo e (a repetição do Dó $_{3}$ como um pedal ou ponto de partida) interagem antes do arpejo final que desce para o grave (c.351-352). 


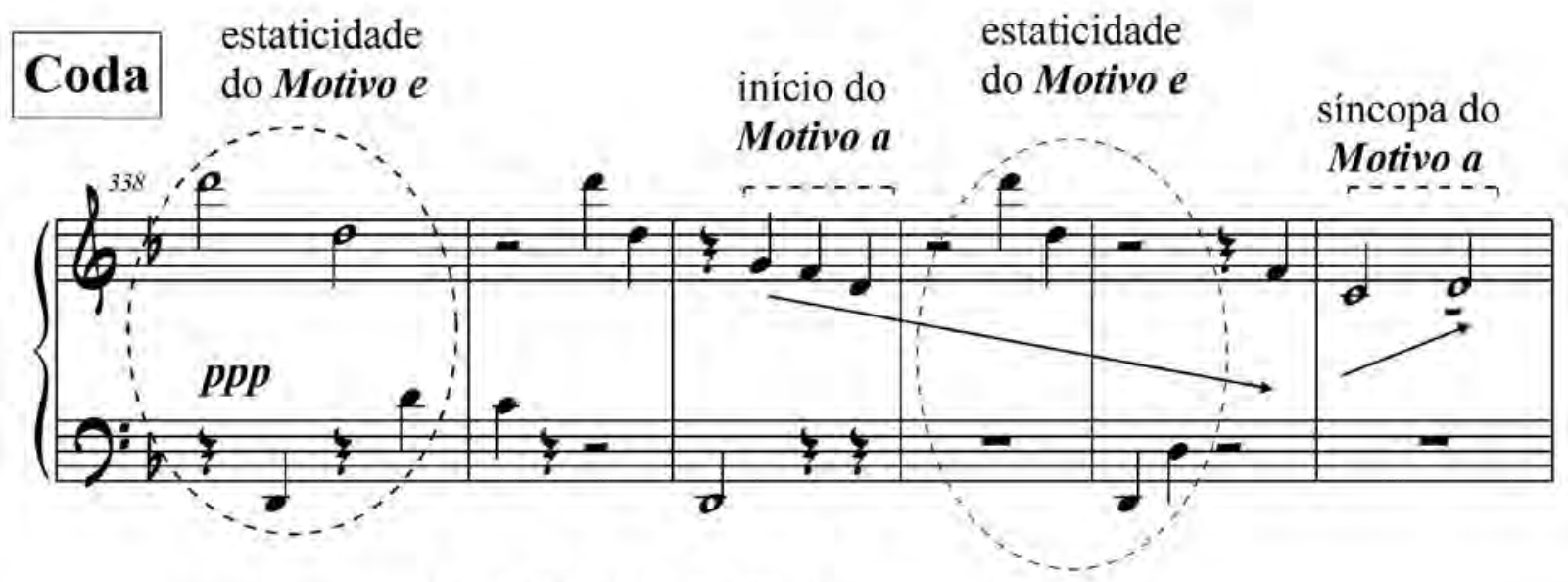

fragmentação e expansão do Motivo a (sincopa) + Motivo b (escala) + Motivo e (ostinato)

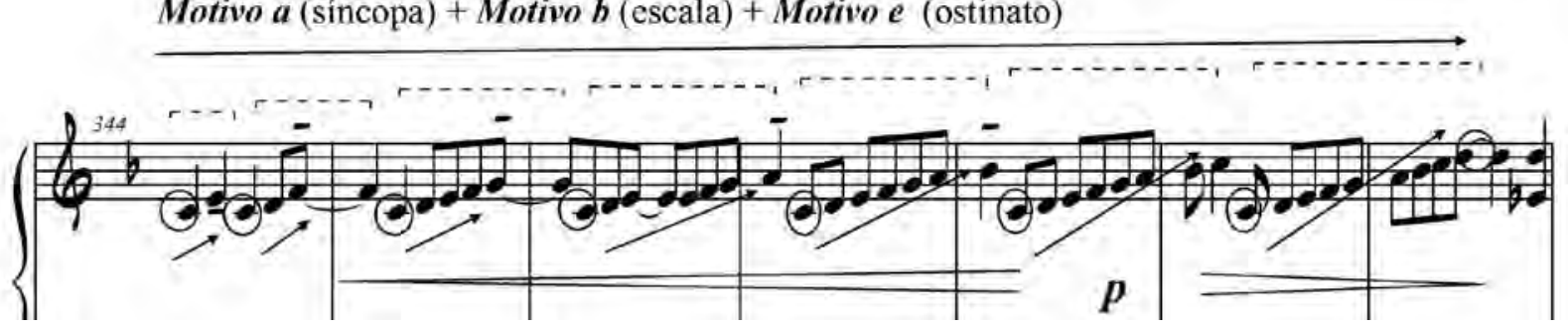

Ex.23 - Coda de Frevo, na qual Gismonti obtém um anticlímax por meio de fragmentação e expansão temática dos Motivos a, b, c, e, rarefação rítmica e baixas dinâmicas.

\section{5 - Conclusão}

A canção instrumental Frevo pode ser tomada como um mostruário das influências estilisticas europeias que formaram o compositor e multi-instrumentista Egberto Gismonti: os exercício técnicos dos métodos de piano, o contraponto de J. S. Bach, o pianismo romântico de F. Chopin, o desenvolvimento temático da Primeira e Segunda Escolas de Viena, a utilização coloristica e espacializada do som - inclusive o som sintetizado -, muita evidenciada na música pós-1950. Por outro lado, Frevo também ilustra seu apego ao nacionalismo brasileiro, que valoriza seus gêneros musicais a partir do modelo deixado por H. Villa-Lobos. No seu hibridismo, Gismonti sugere a simplicidade da música pernambucana ao lado de sofisticados procedimentos composicionais (evidentes na forma, harmonia e desenvolvimento temático) e de performance (evidentes nos seus procedimentos de improvisação e técnica instrumental).

Gismonti se atém à simplicidade harmônica geralmente encontrada no gênero frevo, evitando modulações e mantendo o centro tonal em torno de Ré Menor durante toda a peça. Entretanto, cria um espaço mínimo de divagação ao flutuar para modos de tônicas correlatas, como Ré Eólio, Ré Dórico e Ré Frígio. Ele obtém grande unidade composicional em Frevo ao derivar todas as relações formais e estilísticas de cinco motivos temáticos apenas, quatro dos quais são apresentados logo no início da peça. Ele utilizou diversos procedimentos para ampliar e inovar a forma canção simples (Seção I - Seção II - Seção I) típica do frevo: (1) a repetição de Subseções com pequenas ou grandes variações melódicas, ritmicas e harmônicas; (2) a inclusão de uma Ponte autônoma, em que um novo motivo é apresentado; (3) uma grande ampliação da recapitulação da Seção / por meio de improvisação sobre os choruses das Subseção $A$ (principalmente de $A^{3} a A^{\prime \prime}$ ) e Subseção $B(4)$ a inclusão de uma Coda construída com materiais temáticos que vão se dispersando, contrariando os finais apoteóticos e carnavalescos típicos dos frevos.

Uma das caracteristicas mais marcantes de Frevo é o grau de virtuosismo empregado na complementaridade entre as mãos direita e esquerda no piano, cujo contraponto, ao mesmo tempo em que eleva o discurso musical a um alto grau de complexidade, mas que não quer se afastar da música popular, também permite manipulações envolvendo reharmonização, apresentação a capella, fragmentação, diminuição, aumentação, inversão, espacialização, justaposição e combinação dos materiais temáticos. Por outro lado, o contraste - e alívio - à agitação gerada pelo contraponto da maioria das Subseções $A$ e $B$ e suas variações é provida por esporádicas texturas de natureza homofônica que ocorrem na Ponte e nas Subseções $C$ e $D$. 
Para finalizar, recorremos às duas epígrafes que escolhemos para iniciar esse artigo. Como o próprio gênero frevo - que resistiu ao "poder das elites" e ainda "resiste aos poderes do mercado" (MÜLLER, 2006) - a música de Gismonti resistiu e ainda resiste aos estereótipos que 0 mercado da música de consumo busca impor aos gêneros populares. Se o caos do Frevo de Egberto Gismonti "fere" os ouvidos - como é próprio do gênero frevo "ferir" (MÜLLER, 2006) - , especialmente nas primeiras audições, esta pequena obra-prima se revela como um universo altamente organizado em torno de poucos elementos rica e criativamente organizados.

\section{Referências de texto}

ANDRADE, Maria do Carmo. Frevioca. Fundação Joaquim Nabuco, Biblioteca Blanche Knopf. Disponivel em: <www. basilio.fundaj.gov.br/pesquisaescolar> (Acesso em 25 de janeiro 2013).

ANDRADE, Cisneiro Soares de. Galo da Madrugada: mudanças ocorridas nos trinta anos de existência do Clube. João Pessoa. UFB, 2008. (Dissertação de Mestrado em Música).

CRYSÓSTOMO, Antônio. Enfim popular. Revista Veja. Seção Música. 13 de outubro de 1976.

DANTAS, Leonardo. Entrevista, Leonardo Dantas: antes era uma paixão, hoje é negócio. In: Algomais, a Revista de Pernambuco. Ed. Adriana Coutinho. n.59; 4 de fevereiro de 2010. p.10-12. Disponível em: <www.revistaalgomais. ne10.uol.com.br/blog/wp-content/ea/edica059.pdf> (Acesso em 25 de janeiro 2013).

FREGTMAN, D. Carlos. Música transpessoal: uma cartografia holística da arte, da ciência e do misticismo. Tradução de Maria Stela Gonçalves. Depoimento de Egberto Gismonti. São Paulo: Editora Cultrix, 1989.

GODOY, Sibila. Dança das cabeças: a trajetória musical de Egberto Gismonti. Pesquisa e Música. v.5 n.1. Rio de Janeiro: Conservatório Brasileiro de Música, 2000. p.58-66.

GILMAN, Bruce. $E G=m^{2}$ : there seem to be no horizon for composer and multi-instrumentalist Egberto Gismonti as crosses another threshold with his latest release Meeting point. In: Brazzil: since 1989 trying to understand Brazil. Depoimento de Egberto Gismonti a Bruce Gilman realizada em junho de 1998. Disponível em: www.brazzil.com/ musjun98.htm. (Acesso em 5 de fevereiro, 2013).

LÉLIS, Carmem (Org.). Dossiê de candidatura: frevo, patrimônio cultural imaterial do Brasil. Brasilia: IPHAN, 2007. Disponivel em: <www.portal.iphan.gov.br/portal> (Acesso em 28 de janeiro, 2013). 151p

LIMA, Sérgio Ricardo de Godoy. O Piano mestiço: composições para piano popular com acompanhamento a partir de matrizes pernambucanas. Campinas: UNICAMP, 2005 (Dissertação de Mestrado em Música).

McGOWAN, Chris; PESSANHA, Ricardo. The Bilborad book of Brazilian music: samba, bossa nova and the popular sounds of Brazil. Prefácio de Paul Winter. New York: Guiness Publishing 1991.

MÜLLER, Elaine. Texto - frevo: Frevo: patrimônio cultural brasileiro. Parecer 001/06 da 5a SR do IPHAN. Brasília: IPHAN, 5 de dezembro de 2006. Disponivel em: <www.portal.iphan.gov.br/portal> (Acesso em 28 de janeiro, 2013).

OLIVEIRA, Thiago Chaves de Andrade. Sérgio Assad: sua linguagem estético-musical através

da análise de Aquarelle para violão solo. São Paulo: USP, 2009 (Dissertação de Mestrado em Música).

RABELLO, Evandro. Memórias da folia: o carnaval do Recife pelos olhos da imprensa (1822-1925). Recife: Funcultura, 2004.

SÁ, Paulo. 0 Improviso no choro. Pesquisa em Música. v.5, n.1. Rio de Janeioro: Conservatório Brasileiro de Música, 2000. p.66-70.

SALDANHA, Leonardo Vilaça. Frevendo no Recife: a música popular urbana no Recife e sua consolidação através do rádio. Campinas: UNICAMP, 2008. (Tese de Doutorado em Música).

SANT'ANNA, Márcia Genésia. Certidão - frevo. Brasília: Brasília: IPHAN, 28 de fevereiro de 2007. Disponível em: <www. portal.iphan.gov.br/portal> (Acesso em 28 de janeiro, 2013).

SILVA, Cândida Luiza Borges da. A Interpretação e o pianismo de Egberto Gismonti em sua obra "Sonhos de Recife". Rio de Janeiro: UFRJ, 2005. (Dissertação de Mestrado em Música). 
SILVA, Leonardo Dantas da; SOUTO MAIOR, Mário. Antologia do carnaval de Recife. Ed. pela Fundação Joaquim Nabuco. Recife: Massangana, 1991.

SCHOENBERG, Arnold. Coherence, counterpoint, instrumentation, instruction in form. Trad. Charlotte M. Cross e Severine Neff. Publicado anteriormente em 1917. Ed.Severine Neff. Lincoln: University of Nebraska Press:Lincoln, 1994.

Funções estruturais da harmonia. Trad. de Eduardo Seincman, Ed. Leonard Stein. São Paulo: Via Lettera, 2004 [1969].

The Musical Idea and the logic, Ttechnique and art of its presentation. Publicado anteriormente em 1995. Ed. de Patricia Carpenter e Severine Neff. Bloomington: Indiana University Press, 2006.

VALADARES, Paula Viana Rezende e. O Frevo nos discos da Rozenblit: um olhar de

designer sobre a representação da indústria cultural. Recife: UFPE, 2007 (Dissertação de Mestrado em Design).

VILA NOVA, Júlio César Fernandes. O Frevo no discurso literomusical brasileiro:

ethos discursivo e posicionamento. Recife: UFPE, 2012 (Dissertação de Doutorado em Letras).

BERNOTAS, Bob. Egberto Gismonti: 2008 Art of Jazz Lifetime Achievement Award Winner. Texto de 2008. Disponivel em: <www.artofjazz.org/artist-biographies/2012/05/egberto-gismonti> (Acesso em 28 de janeiro, 2013).

RIBEIRO, Silas Azevedo. O frevo: as características do ritmo e estilo. Texto de 7 de novembro, 2008. Disponivel em: <www. webartigos.com/artigos/o-frevo-as-caracteristicas-do-ritmo-e-estilo/10969/ > (Acesso em 28 de janeiro, 2013).

WANDER, Edson. Ele, Egberto. Disponivel em: <www.overmundo.com.br/overblog/ele-egberto $>$. Texto de 7 de junho, 2007 (Acesso em 28 de janeiro, 2013).

AMARAL, Carlos Eduardo. Egberto Gismonti: "O único objetivo que tenho é dar toda a minha obra". In: Continente Online. Texto de 01 de abril, 2007. Disponivel em: <www.revistacontinente.com.br/index.php/component/content/ article/2478.html> (Acesso em 28 de janeiro, 2013).

MELO, Rúrion Soares. O "popular" em Egberto Gismonti. In: Novos Estudos CEBRAP, 78. Texto de julho de 2007. Disponivel em: <www.scielo.br/pdf/nec/n78/15.pdf> (Acesso em 28 de janeiro, 2013). p.191-200

PIRES, Pablo. Gismonti quer ceder seus direitos autorais. Texto de 21 de abril de 2004, publicado no jornal 0 tempo. Disponivel em: <www.clubedejazz.com.br/noticias/noticia.php?noticia_id=102> (Acesso em 28 de janeiro, 2013).

\section{Referências de partituras}

BACH, J. S. Prelúdio N.3, BWV 848. In: Das Wohltemperierte Klavier. Parte 1. Dedilhados de Hans-Martin Theopold. Munique: G. Henle Verlag, 1997. p.10.

BACH, J. S. Prelúdio N.22, BWV 867. In: Das Wohltemperierte Klavier. Parte 1. Dedilhados de Hans-Martin Theopold. Munique: G. Henle Verlag, 1997. p.107.

CHOPIN, F. Étude Op. 25 № 8. In: Chopin Complete Works: Studies. v.2. 29a ed. Editado por I. J. Paderewski, L. Bronarski e J. Turczyński. Cracóvia: The Fryderyk Chopin Institut/Polish Music Publications, 1949.

GISMONTI, Egberto. Frevo. Switzerland: Éditions Gismonti, s.d. p.3 (folhas de caderno contendo partituras de Frevo, Nó Caipira, Solo, Sanfona, Alma brasieira, Friday night in San Francisco, Christiane Legrand).

GISMONTI, Egberto. Frevo. In: Alma. Rio de Janeiro: EMI-Odeon Fonográfica, 1987b. Relançado em 1993 pela Tom Brasil Produções Musicais Ltda. (Partitura do encarte do CD, no 529123-2).

GISMONTI, Egberto. Frevo. Transcrição e edição de Marcelo G. M. Magalhães Pinto e Fausto Borém. Per Musi. n.28. Belo Horizonte: UFMG, 2013. p.125-144.

\section{Referência de áudio}

GISMONTI, Egberto. Frevo. In: Alma. Egberto Gismonti, piano e sintetizadores; Nando Carneiro, sintetizadores. Rio de Janeiro: EMI-Odeon Fonográfica, 1987a. Relançado em 1993 pela Tom Brasil Produções Musicais Ltda. (CD de áudio, $n^{\circ}$ 529123-2).

\section{Referência de vídeo}

GISMONTI, Egberto. Frevo (Egberto Gismonti). Depoimento de Egberto Gismonti. In: Programa Ensaio, TV Cultura, 1992. Vídeo de 05 minutos e 32 segundos, postado no Youtube por "Marcos Felício" em 31 de janeiro de 2009. (Acesso em 30 de janeiro, 2013). 


\section{Notas}

1 A polêmica sobre a aceitação do frevo cantado teve em Ariano Suassuna importante defensor na década de 1950 e em Ruy Duarte seu principal detrator no final da década de 1960 (VILA NOVA, 2012, p.35-42).

2 A utilização da frevioca, o trio elétrico pernambucano, cuja origem parece estar ligada à imagem de uma carroça com uma orquestra, é creditada ao jornalista e escritor pernambucano Leonardo Dantas. Em 1979, enquanto era Diretor da Fundação de Cultura da Cidade do Recife e devido a restrições orçamentárias da prefeitura, ele experimentou colocar bandas de frevo e solistas (notadamente o cantor Claudionor Germano e a Orquestra popular do Maestro Ademir Araújo) em caminhões ambulantes para as multidões no centro de Recife. A partir de 1983, a frevioca passou a ser utilizada pelo Galo da Madrugada, considerado o maior bloco de carnaval do mundo (M. C. ANDRADE, 2013; DANTAS, 2013; C. S. ANDRADE, 2008, p.95-96).

Marcelo G. M. Magalhães Pinto é Doutorando em Jazz Performance na Eastman School of Music em Rochester, NY e Mestre em Música pela UFMG. Participou de diversos festivais nacionais e internacionais como o Savassi Jazz Festival e Xerox International Rochester Jazz Festival. Participou da Orquestra Sinfônica da Unesco sob a regência de Francis Hime por ocasião do encerramento do Ano Brasil-França. Recebeu diversos prêmios no Brasil e no exterior como performer e arranjador. Lançou o Cd Paisagens de Minas em 2009 pelo selo Karmim.

Fausto Borém é Professor Titular da Escola de Música da Universidade Federal de Minas Gerais (UFMG), onde criou o Mestrado e a Revista Per Musi. É pesquisador do CNPq desde 1994 e seus resultados de pesquisa incluem dois livros, três capítulos de livro, dezenas de artigos sobre práticas de performance e suas interfaces (composição, análise, musicologia, etnomusicologia e educação musical) em periódicos nacionais e internacionais, dezenas de edições de partituras e recitais nos principais eventos nacionais e internacionais de contrabaixo. Recebeu diversos prêmios no Brasil e no exterior como solista, teórico, compositor e professor. Acompanhou músicos eruditos como Yo-Yo Ma, Midori, Menahen Pressler, Yoel Levi, Arnaldo Cohen e músicos populares como Hermeto Pascoal, Egberto Gismonti, Henry Mancini, Bill Mays, Kristin Korb, Grupo UAKTI, Toninho Horta, Juarez Moreira, Tavinho Moura, Roberto Corrêa e Túlio Mourão. Participou do CD e DVD 0 Aleph de Fabiano Araújo Costa. 